\title{
Macroprudential Policy Effectiveness: Lessons from Southeastern Europe
}

\author{
Jérôme Vandenbussche ${ }^{1}$ \\ International Monetary Fund \\ jvandenbussche@imf.org \\ Piyabha Kongsamut \\ International Monetary Fund \\ pkongsamut@imf.org \\ Dilyana Dimova \\ International Monetary Fund \\ ddimova@imf.org
}

\begin{abstract}
This paper presents a detailed account of the rich set of macroprudential measures (MPPs) implemented in Bulgaria, Croatia, Romania, and Serbia during their synchronized boom and bust cycles in 2002-12, and assesses their effectiveness in managing credit growth. Only strong MPPs helped contain domestic credit growth during the boom years, but circumvention via direct external borrowing offset their effectiveness to a large extent. MPPs taken during the bust had no discernible impact. The paper concludes that (i) proper calibration of MPPs is of the essence; (ii) only strong, broad-based MPPs can contain credit booms; (iii) econometric studies of macroprudential policy effectiveness should focus on concrete policy measures rather than on instruments use; and (iv) in so doing should allow for possible non-linear and state-contingent effects.
\end{abstract}

JEL Classification: G18, G28

Keywords: Macroprudential Policies, Financial Stability, Credit Growth, Southeastern Europe

\section{INTRODUCTION}

In the wake of the global financial crisis (GFC), interest in macroprudential policy and its ability to manage the financial cycle has grown tremendously. Such policies, aimed at reducing the risk and the macroeconomic costs of financial instability, are gaining a much more prominent role in policy frameworks, alongside fiscal and monetary policy. Given the limited experience in

1 Corresponding author. Address: International Monetary Fund, $70019^{\text {th }}$ street NW, Washington, DC 20431. Phone: $+1202-623-6676$. Email: jvandenbussche@imf.org 
their implementation, finding out whether and how they can achieve their objectives is now high on policy-makers' agenda in most advanced and emerging market countries.

This paper assesses the effectiveness of macroprudential policy measures (MPPs) in four neighboring Southeastern European emerging economies (Bulgaria, Croatia, Romania and Serbia) during their recent synchronized financial cycle $(2002-12),{ }^{2}$ with a view to drawing lessons for both policy-makers and researchers. The four countries were subject to a similar external macro-financial environment and were going through similar processes of economic convergence and financial deepening, including as part of the process of joining the European Union (EU), though they were at different stages of accession. Their similarity is also exemplified by banking systems that were dominated by subsidiaries of large Western European banks, and were highly euroized (see Appendix 1). They all experienced strong capital inflows and credit growth during the boom period running up to the fourth quarter of 2008, and then a sudden stop, followed by a protracted recession. Their prudential authorities actively adopted MPPs to try and manage these developments. At the same time, initial conditions in banking system sizes and monetary policy regimes differed, and the set of policy instruments deployed varied. The combination of many shared elements of context and heterogeneous policy responses makes it interesting to exploit synergies in a joint study of the four countries. ${ }^{3}$

During the boom years, monetary policy was mostly focused on inflation and exchange rate developments and did not explicitly target credit or asset price developments. Fiscal policy was generally pro-cyclical, at best acyclical. That left macroprudential policy in the front line to manage the financial cycle. It was implemented outside of a dedicated formal policy framework. The monetary and prudential authorities - both part of the central bank in the four countries interpreted their mandate to include macro-financial stability objectives. The choice of instruments varied over time as conditions changed. Seen in a broader European context, the four countries were pioneers in the use of MPPs. ${ }^{4}$

The paper implements a case study methodology, and aims to provide a useful complement to the burgeoning econometric literature on macroprudential policy effectiveness. Indeed, the bulk of this literature often does not capture well either the diversity in MPP design or the strength of the measures taken. This latter flaw is reflected in many papers' focus on instruments (i.e. MPPs abstracted from their calibration and implementation context) and categorical conclusions about instrument effectiveness (i.e. an instrument is, or is not, effective) whereas we suspect that effectiveness crucially depends on both context and proper calibration. We therefore find it more useful to discuss measure effectiveness. Furthermore, the effect of MPPs can in principle be highly non-linear, but the econometric studies that take into account measure strength of which we are aware are all based on linear specifications.

A case study methodology is flexible enough to address these limitations and also allows for providing a richer context about policy motivation and implementation. In Appendix 2, we thus provide a detailed discussion of the more than twenty instruments used and the more than one hundred measures implemented, as well as their sequencing, in a cross-country comparative perspective. While we match each type of instrument with a subset of five possible intermediate macro-financial objectives, in this paper we focus on the effectiveness of the measures employed to manage two of these objectives, i.e. total credit growth as well as household credit growth.

Cottarelli, Dell'Ariccia, and Vladkova-Hollar (2005) find that bank-credit-to-GDP ratios in 2002 were near equilibrium and consistent with a process of convergence and structural financial deepening, so 2002 seems a good starting point for the analysis.

The choice of these four countries also reflects the outcome of a trade-off between depth and breadth. Other studies have often analyzed the case of one country in great detail, or the whole Central, Eastern, and Southeastern Europe region in a less granular way. For a broad perspective on the boom-bust cycle in Central, Eastern, and Southeastern Europe, see Bakker and Klingen (2012).

4 The European macroprudential framework was established only in 2011 (ESRB, 2011). 
A companion working paper Dimova, Kongsamut, and Vandenbussche (2016) provides a more extensive discussion of the macroeconomic background of the four countries and assesses the effectiveness of macroprudential measures across two additional objectives (managing the share of foreign currency lending and managing banks' foreign borrowing) as well.

Assessing the effectiveness of MPPs is a challenging task fraught with as many pitfalls and challenges in a case study as in an econometric study. MPPs are most likely endogenous to macro-financial developments and policy-makers' information set and/or expectations are not observable. More broadly, what would have happened had no measures been taken cannot be observed. In particular, it may be the case that the implementation of an MPP prevents an increase in a financial stability risk metric and that as a consequence we observe no change in the relevant metrics and may conclude incorrectly that the measure was not effective. In addition, measures may have been anticipated to various extents, may work with different lags, may not be immediately binding, and may interact with each other.

Against that background, we aim to identify which measures are associated with a sign of effectiveness, i.e. credit growth (or household credit growth) visibly moving in the intended direction within a window of four quarters around the time of implementation of the measure. Because we assess one measure at a time - rather than lump all measures of the same type together - we can discriminate across directions of policy change (tightening versus easing), implementation context (e.g. boom versus bust), and strength. However, because several measures may have been taken in the same time window, our inference remains tentative.

An important aspect the paper does not address is whether the MPPs helped build sufficient capital and liquidity buffers to preserve financial stability during the bust. The banking systems of the four countries remained broadly stable and only a few small domestically-owned banks failed during the bust period (2008:Q4-2012:Q4). However, this robustness was likely partially due to the fact that many foreign-owned parent groups received capital and funding support from their own home country's governments and that this support was in part needed because of the deterioration in the outlook of these groups' operations in Central, Eastern and Southeastern Europe (CESEE). Furthermore, in the case of Romania and Serbia, macroeconomic stabilization programs with official external financing were rapidly put in place, and helped shore up confidence.

Keeping the above caveats in mind, the paper's main findings can be summarized as follows: only strong measures helped contain domestic credit growth during the boom years, but the impact of these measures was weakened because of circumvention. Turning to the specifics, key findings for the boom period are that: (1) binding marginal reserve requirements related to credit growth ("credit growth ceilings") helped contain domestic credit growth; (2) strong sectoral capital measures and (3) the introduction of meaningful loan-to-value and debt-serviceto-income ceilings helped limit household credit growth; however, (4) circumvention via direct external borrowing largely offset the direct effect of (1)..$^{5}$ A corollary is that the other, less strict measures (the vast majority) are not associated with a sign of effectiveness. In a few cases, lessimmediately-binding loan classification and provisioning measures were taken concurrently with the strong measures we find to be effective and may have reinforced their effect. Measures taken during the bust had no discernible impact.

While optimal calibration of measures obviously depends on country circumstances, the specifics of a few measures we find effective can provide a sense of the magnitudes involved, keeping in mind that the effect of some measures may have been reinforced by other measures taken concurrently or soon afterwards. Credit growth ceilings involved marginal reserve requirements of 200 percent when quarterly credit growth exceeded 4 percent (Croatia, 2003:Q1). Risk-weights on mortgages with loan-to-value (LTV) ratio above 70 percent were increased

For lack of publicly available data, we cannot assess the extent of the circumvention of (1)-(2) via borrowing from domestic nonbanks. An assessment of circumvention of (3) requires granular data, also not publicly available. 
from 50 percent to 100 percent (Bulgaria, 2005:Q3). An LTV ceiling of 75 percent was introduced (Romania, 2004:Q1). These were not trivial measures by any reasonable standard.

Our study of the experience of these four countries suggests one lesson for policy-makers and two lessons for researchers. The lesson for policy-makers is that only strong, broad-based MPPs which address possible circumvention channels have a chance to truly contain credit booms. The first lesson for researchers is that the focus of effectiveness studies should be placed on measures and their strength rather than on instruments (i.e. classes of measures) and their mere deployment. The second lesson is that the possibility of non-linear effects (e.g. the existence of thresholds or asymmetries between tightening and easing) and state-contingent effects (e.g. differences between good times and bad times) should be taken into account in econometric studies.

The rest of the paper is organized as follows. After a review of the literature in Section II, the set of macroprudential policy instruments and the set of policy objectives these instruments can help achieve is presented in Section III. Section IV assesses the effectiveness of all relevant macroprudential policy measures by analyzing the evolution of domestic credit growth and domestic household credit growth around the time of their implementation. Section V discusses to what extent circumvention can affect this assessment, by looking at the concurrent evolution of cross-border lending. Section VI concludes, and is followed by a short appendix table of selected macro-financial indicators. Appendix 2 presents the list of MPPs implemented by the four countries in full detail.

\section{LITERATURE REVIEW}

An analysis of the key aspects of macroprudential policy design and reviews of the burgeoning literature on the subject can be found in IMF (2013a, 2013b and 2014) and Claessens (2015). Our review centers on the smaller set of empirical studies devoted to the effect of macroprudential policy on credit growth.

Most studies covering relatively large samples of countries have usually focused on instrument effectiveness rather than measure effectiveness, thus largely ignoring the issue of instrument calibration. Lim et al. (2011) find that several instruments - LTV cap, debt-service-to-income cap (DSTI), credit growth ceiling, foreign currency lending ceiling, reserve requirements, dynamic provisioning, and countercyclical capital requirements - reduce the procyclicality of credit and/or bank leverage in a panel of 49 countries between 2000 and 2010. Focusing on the same countries and period and the same MPP dataset, but using bank-level data, Claessens, Ghosh and Mihet (2013) find that measures aimed at borrowers (LTV and DSTI), and at financial institutions (credit growth ceilings) are effective at reducing asset growth, and that countercyclical buffers are of little effectiveness through the cycle.

Dell'Ariccia et al. (2012) find that a stricter MPP stance (measured as a count of macroprudential instruments in use or as an aggregate indicator variable) reduces the incidence of credit booms and decrease the probability that booms end badly. Zhang and Zoli (2014) find that LTV, housingrelated taxes, and foreign currency-related measures have helped curb credit growth, in a set of 46 countries during 2000-13. Examining MPPs in 119 countries over 2000-13, Cerutti, Claessens and Laeven (2015) find that borrower-based policies and financial-institutions-based policies are associated with lower growth in credit to households in emerging market economies. Exploiting data from 57 countries spanning more than three decades, Kuttner and Shim (2013) find that only changes in DSTI have a robust statistically significant effect on housing credit growth. Vandenbussche, Vogel, and Detragiache (2015) look at household credit growth in sixteen CESEE countries between the late 1990s and 2011 and find that, among a large set of instruments, only changes in the minimum capital adequacy ratio and credit growth ceilings had a significant effect. In contrast with the rest of the existing literature, their paper actually quantifies MPP strength and 
can therefore speak to the issue of calibration. We use their scoring methodology to produce two figures in Section III below.

Among studies that focus on a narrower set of instruments, Dassatti Camors, and Peydro (2014) and Tovar Mora, Garcia-Escribano, and Vera Martin (2012) find that credit growth has positively responded to higher reserve requirements (RRs) in Latin America, while other studies found that tightening LTV and/or DSTI together slowed housing credit growth in Hong-Kong (Ahuja and Nabar, 2011), Korea (Igan and Kang, 2012), and selected emerging market economies (Jacome and Mitra, 2015). Aiyar, Calomiris, and Wieladek (2014) estimate the quantitative effect of an increase in regulated banks' capital requirements on lending growth in the United Kingdom. They also provide evidence of partial circumvention via unregulated resident foreign branches.

Many studies of CESEE economies focus on how various types of MPPs helped regulate credit growth during the latest boom-bust cycle in individual countries ${ }^{6}$ - Estonia (Sutt, Korju, and Siibak (2011)), Hungary (Banai, Király, and Nagy (2011)), Macedonia (Celeska, Gligorova, and Krstevska (2011)), and Poland (Kruszka and Kowalczyk (2011)). Of particular relevance to our study is Galac (2010) who finds that credit growth ceilings, MRR on foreign borrowing, foreign currency liquidity ratio measures, and high capital adequacy requirements were particularly useful in building liquidity and capital buffers, but less effective in slowing down credit growth and capital inflows. He also finds that credit growth ceilings (the so-called credit growth reserve) were successful in reducing the rate of domestic credit growth, but were largely unsuccessful in reducing the growth of total private sector debt, particularly for corporations, due to widespread circumvention via external borrowing. This finding is broadly confirmed in our study. Gersl and Jasova (2014) also document that the most common circumvention in CESEE during the recent boom was to switch to direct cross-border borrowing from the foreign parent banks or to shift to less supervised channels such as leasing companies.

Kraft and Galac (2011) fine-tune Galac (2010)'s analysis and find that while the credit growth ceilings did nothing to the growth of total non-financial corporations' debt, they did slow down the growth of total household debt. Neagu, Tatarici, and Mihai (2015) discuss Romania's experience with DSTI and LTV in detail, and confirm, as we do, that the introduction of these instruments in 2004 slowed down household credit growth. As these authors, we analyze the use and effectiveness of MPPs against the background of particular macroeconomic contexts but delve into the design and calibration of the MPPs in greater detail.

\section{POLICY INSTRUMENTS AND OBJECTIVES}

\subsection{Policy Instruments}

To obtain data on MPPs for 2002-12 and establish the list of instruments used, we complement data from the Vandenbussche, Vogel and Detragiache (2015) database (which covers 2002-10) with data from various sources, including financial stability reports and annual reports published by the four countries' central banks, for 2011 and 2012.

The key prudential instruments used by the Bulgarian National Bank, the Croatian National Bank, the National Bank of Romania, and the National Bank of Serbia during 2002-12 can be grouped into six broad categories:

1. Capital regulation (CAP), including minimum capital adequacy ratio, bank-specific capital adequacy minima that depend on credit growth, risk-weights, sectoral leverage ratios, and capital eligibility (e.g. the treatment of current profits). While all four countries took CAP

See also Enoch and Ötker-Robe (2007) for experiences with MPPs in CESEE during the first half of the boom. 
measures, they resorted to somewhat different strategies during the boom years, reflecting initial conditions of their banking regulation and of the size and composition of their banking sector's loan portfolio. Most banks operated in a situation of excess capital over minimum requirements; therefore, tightening measures had the goal of maintaining sufficient buffers rather than building them, and/or affecting the allocation of credit across sectors and currencies.

2. Loan classification and provisioning rules (LCP), including rules for specific provisions and rules for general provisions. During the boom, the four countries made their loan classification and provisioning rules stricter so as to require banks to build thicker provisioning buffers and provide greater incentives for more careful loan underwriting. All countries changed the rules governing specific provisions, i.e. those provisions made against loan exposures that do not meet the criteria to belong to the safest category. Two countries also introduced a system of general provisions, i.e. provisions that are contingent neither on the characteristics nor on the performance of the loan and have built-in countercyclical features.

3. Liability-based reserve requirements and liquidity ratios (LRR), including average reserve requirements, marginal reserve requirements on foreign liabilities, and foreign-currency liquidity ratio (FCLR). During the bust, these were among the earliest to be loosened to help relieve liquidity pressures in banking systems.

4. Asset-based reserve requirements (ARR), including marginal reserve requirements related to credit growth. Croatia and Bulgaria aimed to control credit growth by deploying this category of instruments. Neither Romania nor Serbia used them.

5. Eligibility requirements (ELI), including LTV caps, and DSTI caps, which constrain credit demand by placing caps on the amounts that can be borrowed. Only Romania made use of this type of instrument during the boom.

6. Non-bank regulation (NBK), including regulation of leasing and consumer finance companies. Partly as a result of the stricter regulation imposed on banks, nonbank credit institutions began to thrive, although the size of these sectors remained very small relative to the size of the banking sector. Romania and Serbia brought these institutions into the regulatory perimeter during the boom period.

The first four categories of measures affect various cost margins as well as capital, provisions and liquidity buffers. They work through the supply side of credit, while the fifth category affects the demand side of credit. The sixth category works by constraining the activity of nonbank credit intermediaries, which can be a channel of circumvention of measures targeting banks only. As indicated in the introduction, a comprehensive list of measures is provided in Appendix 2.

The four countries varied in their degree of interventionism. Generally, countries tended to tighten the macroprudential policy stance during the boom period and loosen it during the bust period (see Figures 1 and 2). During the boom, policymakers at times implemented various instruments simultaneously. This approach suggests that macroprudential authorities believed in instrument complementarity. The progression observed over time also likely reflects a sequential approach where the more intrusive measures were used only after less severe measures had been first tried and, presumably, found not to have the desired impact. 


\section{Figure 1.}

Changes in Macroprudential Policy Stance during the Boom (changes relative to 2002:Q3)
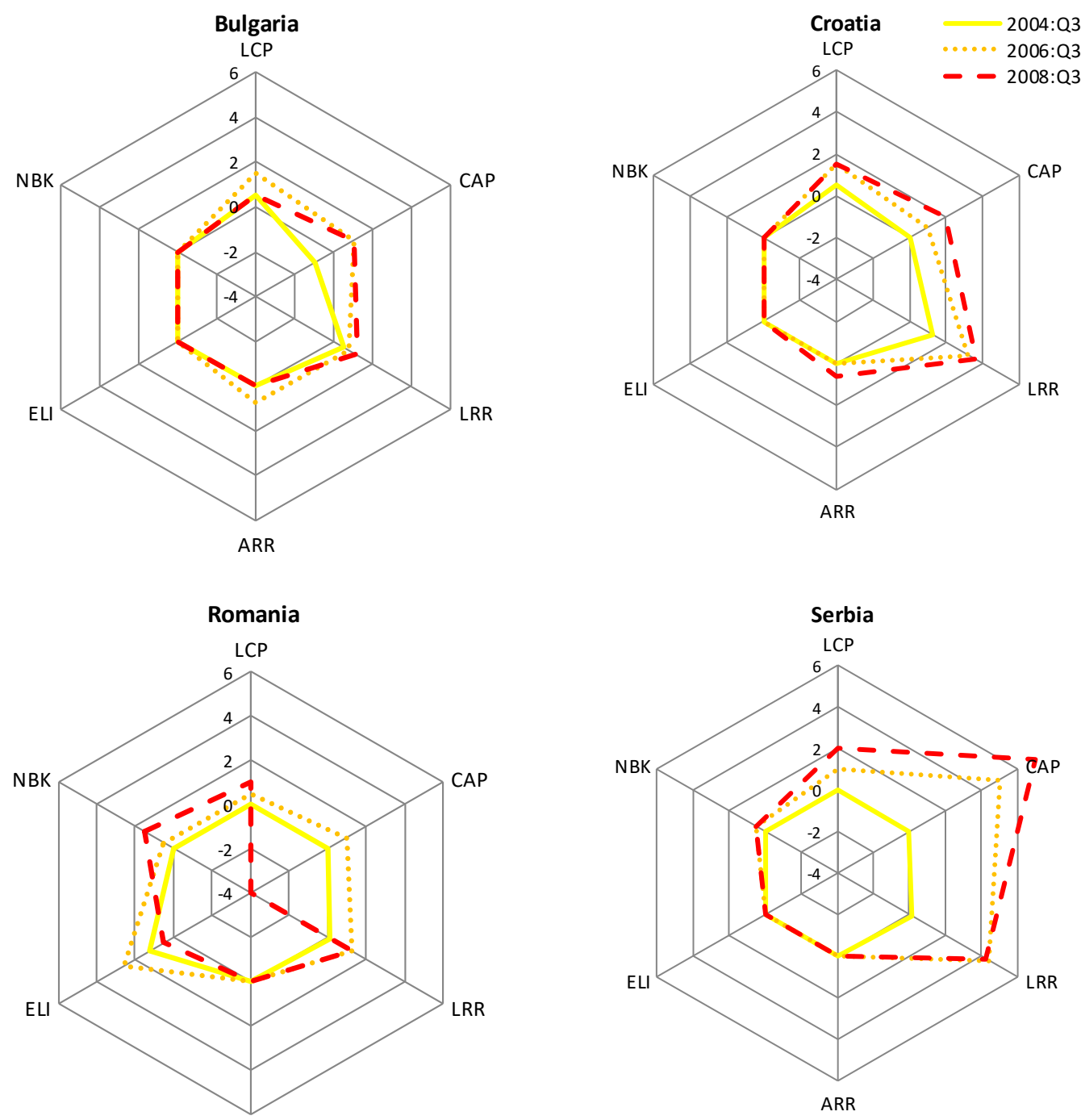

ARR

CAP: Capital Regulations

LCP: Loan Classification/Provisioning

LRR: Liability-Based Reserve

Asset-Based Reserve

Requirements

ELI: Loan Eligibility Requirements

Requirements and Liquidity Ratios

NBK: Non-bank Regulation

Note: A higher value corresponds to a tighter stance.

Source: Authors' calculations based on scoring methodology of Vandenbussche, Vogel, and Detragiache (2015). 
Figure 2.

Changes in Macroprudential Policy Stance during the Bust (changes relative to 2002:Q3)
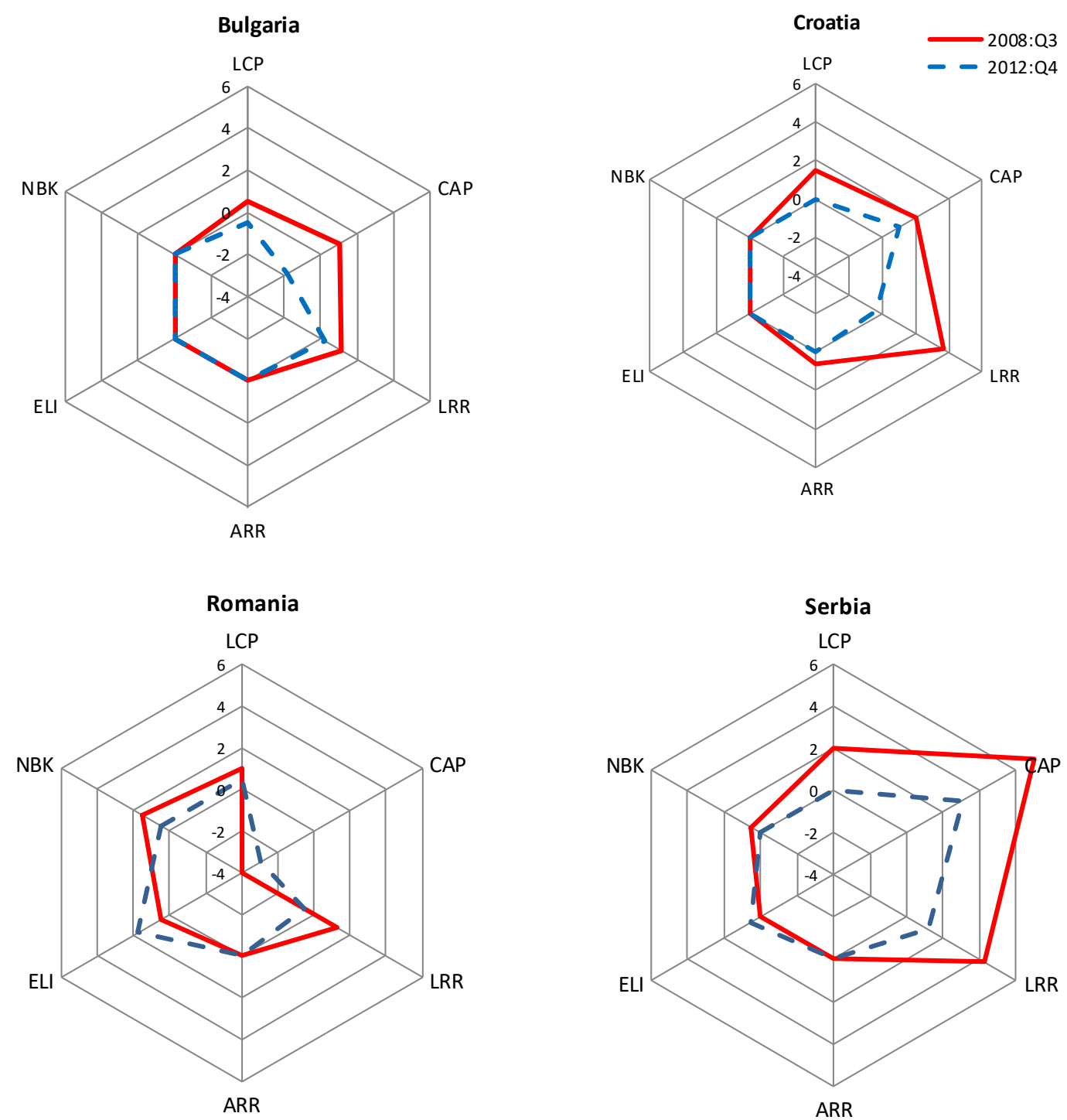

$$
\begin{aligned}
& \text { CAP: Capital Regulations } \\
& \text { LCP: Loan Classification/Provisioning } \\
& \text { LRR: Liability-Based Reserve } \\
& \text { Requirements and Liquidity Ratios }
\end{aligned}
$$

$$
\begin{aligned}
& \text { ARR: Asset-Based Reserve } \\
& \text { Requirements } \\
& \text { ELI: Loan Eligibility Requirements } \\
& \text { NBK: Non-bank Regulation }
\end{aligned}
$$

Note: A higher value corresponds to a tighter stance.

Source: Authors' calculations based on scoring methodology of Vandenbussche, Vogel, and Detragiache (2015).

During the bust, the four countries reversed some of the tightening that had taken place during the boom in order to help banks withstand the global financial crisis and the ensuing recession, and thus help avoid a credit crunch. The most aggressive measures had become redundant and were dropped early. However, and perhaps surprisingly, some tightening during the bust also took place, in particular in the area of loan eligibility criteria. This likely reflects the realization that banks had failed to properly assess credit risk (including the exchange rate risk faced by unhedged borrowers) during the boom years and therefore that further regulatory constraints should be placed on their loan decision-making process. 


\subsection{Policy Objectives}

Though all four countries were experiencing a similar financial cycle, policymakers' perception of risks varied somewhat. Therefore, while their ultimate objective was financial stability - or, more precisely, a balance between supporting economic activity and financial stability $^{7}$ - their intermediate objectives in taking action also varied. Intermediate objectives are defined by the European Systemic Risk Board as "operational specifications of the ultimate objective." ${ }^{\circ}$ Our study evaluates the effectiveness of MPPs against the stated (intermediate) objectives of policymakers in the four countries where these are made explicit, but also in some cases against what is a natural objective given the nature of the instrument (for example, domestic credit growth as an objective for broad-based LRR measures). These objectives are reported in public documents (press releases, annual reports, financial stability reports, etc.), and suggest that concerns were focused on five main intermediate objectives (Table 1). During the boom period, rapid credit growth was a concern in all four countries. Strong household credit growth was being particularly targeted in Bulgaria, Romania and Serbia, therefore we also discuss household credit growth in the context of overall credit growth below. In those same three countries, the relaxation of lending conditions was also a concern.

Table 1.

Macroprudential Policy Intermediate Objectives and Use of Instruments

\begin{tabular}{|c|c|c|c|c|c|}
\hline $\begin{array}{l}\text { MPP } \\
\text { Intermediate } \\
\text { Objectives }\end{array}$ & $\begin{array}{c}\text { Domestic Credit } \\
\text { Growth }\end{array}$ & $\begin{array}{l}\text { o/w Household } \\
\text { Credit Growth }\end{array}$ & $\begin{array}{l}\text { Lending } \\
\text { Conditions }\end{array}$ & $\begin{array}{l}\text { Share of FC } \\
\text { Lending }\end{array}$ & $\begin{array}{c}\text { Share of Foreign } \\
\text { Borrowing }\end{array}$ \\
\hline $\begin{array}{l}\text { MPP } \\
\text { Instruments }\end{array}$ & $\begin{array}{l}\text { CAP, ARR, LRR, } \\
\text { LCP, ELI, NBK }\end{array}$ & CAP, LCP, ELI & ELI, CAP, LCP & $\begin{array}{c}\text { CAP, LCP, LRR, } \\
\text { ELI }\end{array}$ & LRR \\
\hline Bulgaria & $\mathrm{CC}$ & $\mathrm{CC}$ & $\mathrm{CC}$ & & \\
\hline Croatia & $\mathrm{CC}$ & & & $\mathrm{CC}$ & $\mathrm{CC}$ \\
\hline Romania & partially CC & partially CC & partially $\mathrm{CC}$, then $\mathrm{AC}$ & partially CC & \\
\hline Serbia & $\mathrm{CC}$ & $\mathrm{CC}$ & $\mathrm{AC}$ & partially CC & $\mathrm{CC}$ \\
\hline
\end{tabular}

Notes: $\mathrm{AC}=$ acyclical; $\mathrm{CC}=$ countercyclical; $\mathrm{CAP}=$ capital regulation; $\mathrm{LCP}=$ loan classification and provisioning rules; $\mathrm{LRR}=$ liability-based reserve requirements and liquidity ratios; $\mathrm{ARR}=$ asset-based reserve requirements; $\mathrm{ELI}=$ eligibility requirements; $\mathrm{NBK}=$ regulation of nonbank credit institutions; $\mathrm{FC}=$ foreign currency.

As Table 1 illustrates, the same instrument category was sometimes used for different intermediate objectives. For example, CAP and LCP measures were used for almost all objectives. Other types of measures, such as LRR, were targeted toward more specific objectives of managing the foreign borrowing of banks.

As hinted above, policymakers generally aimed for countercyclical (leaning-against-the-wind) measures. This implies that the tightening measures taken to address the concerns described above were partially or fully reversed during the bust. However, some tightening measures were acyclical in nature and presumably reflected policymakers' realization that stricter regulation was required to reduce systemic risk regardless of the position in the financial cycle. In addition, in the case of Bulgaria and Romania, some measures taken for countercyclical reasons during the boom were later reversed in the context of harmonization with EU regulation, thus limiting their overall impact.

\footnotetext{
The relative weight placed on growth considerations reflected initial conditions in terms of financial sector development See ESRB (2011).
} 


\section{WERE CREDIT GROWTH MEASURES EFFECTIVE?}

We now turn to the assessment of the measures' effectiveness by analyzing the evolution of two of the specific target variables these measures were meant to affect, namely credit growth and household credit growth. As mentioned in the introduction, an assessment of effectiveness with respect to two other target variables (foreign currency lending, and banks' foreign borrowing) can be found in Dimova, Kongsamut, and Vandenbussche (2016). As noted above, all four countries had concerns about excessive domestic credit growth, and the full range of instruments was deployed. ${ }^{9}$ Our assessment is based on a quantitative criterion specified below and a graphical analysis supported by charts that display the evolution of the target variables over time as well as relevant MPPs that were implemented in the form of vertical lines. These lines are red for tightening measures, green for easing measures, and orange when both a tightening and an easing measure were taken in the same quarter. Shaded areas indicate measures that are deemed effective. Because the share of foreign-currency-denominated loans was high in each country, we examine credit growth adjusted for foreign currency movements to purge the credit series from valuation effects.

The analysis that follows focuses on macroprudential policies and abstracts from the role that monetary policy may have played in the evolution of credit aggregates. This seems appropriate because, to the extent an active monetary policy was pursued, it was mostly focused on inflation and exchange rate developments and generally not (or at least not explicitly) on credit developments. This is obvious in Bulgaria, where the currency board did not allow any independent monetary policy. In Croatia, monetary policy was largely geared toward maintaining exchange rate stability. In Romania, the National Bank of Romania switched to inflation targeting in August 2005 from nominal exchange rate depreciation targeting to curb growing inflation. In spite of missing inflation targets, monetary policy engineered a significant disinflation until 2007 , while credit growth remained untamed. Finally, in Serbia, progress was made with disinflation and from 2006 the focus of monetary policy shifted from the exchange rate to inflation, culminating in the adoption of formal inflation targeting in 2008. In any case, we check that the diagnostics of effectiveness made for each macroprudential measure below is not hampered by a concurrent monetary policy action that would affect domestic credit in the same direction.

The criterion for effectiveness is defined as follows. A measure implemented in period $t$ is deemed effective if the change in credit growth between period $t-2$ and period $t+2$ goes in the right direction and is significant. To reduce the impact of short-term volatility of credit, we use the 3-year moving average of the credit growth series when conducting the assessment. To measure "significance", we construct the series of changes in credit growth (2-period-ahead minus 2-period-behind), separating the periods up to 2007:Q3 (boom) and from 2009:Q3 (bust), i.e. excluding a 7-quarter window around 2008:Q3 (the onset of the Global Financial Crisis, a likely structural break). We then use an iterative procedure for both the boom and the bust. For the boom, we identify the quarter $Q$ when a tightening measure was implemented that is associated with the largest decline in credit growth. We then compute the mean $(\mathrm{m})$ and standard deviation $(s d)$ of the change (between $t-2$ and $t+2$ ) in credit growth during a control period, defined as the period running up to 2007:Q3 excluding a window of seven periods around $Q$ and all other periods previously excluded. The change at time $t$ is deemed significant if the change in credit growth between $t-2$ and $t+2$ is strong enough to be smaller than the threshold $m-1.65 \mathrm{sd} .^{10}$ Assuming we find that the change around quarter $Q$ is significant, we repeat the procedure with the quarter when a tightening measure was implemented that had the second largest negative impact on credit growth, further narrowing the control period. We stop the procedure when we have reached a measure that has an impact that is too small to be lower than the threshold based

Because of data constraints for nonbank financial institutions, the effectiveness of NBK measures cannot be assessed.

10 Ninety percent of a normal distribution of mean $m$ and standard deviation $s d$ is within $[m-1.65 \mathrm{sd}, m+1.65 \mathrm{sd}]$. 
on the relevant control period. We proceed in the exact same way for the bust (using the threshold $m+1.65 \mathrm{sd}$ for easing measures and $m-1.65 \mathrm{sd}$ for the tightening measures), and for household credit growth during the boom and the bust.

In addition, we require that measures found to have an effect on credit growth that is both in the right direction and significant are also found to have an effect on other relevant intermediate targets as the effect on total credit growth is expected to happen via the effect on these other intermediate targets. For example, for measures targeting excessive household credit growth, we require that total credit growth does not decline more than household credit growth (so that the share of household credit in total credit does not increase). ${ }^{11}$

The summary results for effective measures are shown in Table 2. For each measure, we report the change in credit growth taking place around the time when the measure was put in place as well as the relevant threshold. We also indicate whether other reinforcing measures were taken concurrently or subsequently (which would positively bias the diagnostic of effectiveness) and whether the measure reinforced other measures taken earlier (which would negatively bias the diagnostic of effectiveness). In three cases, several measures going in the same direction were taken during the same quarter. We then use judgment to assess whether the policy was sufficiently strong to have been the main reason for the change in credit growth.

Table 2.

Summary of Measures Effective in Managing Domestic Credit Growth (Including measures effective in managing household credit growth)

\begin{tabular}{|c|c|c|c|c|c|c|c|c|}
\hline Type & Instrument & Country & Quarter & Details & $\begin{array}{l}\text { Reinforcing } \\
\text { nature }\end{array}$ & $\begin{array}{l}\text { Reinforcing } \\
\text { measures soon } \\
\text { afterwards }\end{array}$ & $\begin{array}{l}\text { Change } \\
\text { in credit } \\
\text { growth }\end{array}$ & Threshold \\
\hline ARR & Credit ceiling & Bulgaria & 05:Q2 & $\begin{array}{l}\text { Marginal reserve } \\
\text { requirements of } \\
200 \text { percent if } \\
\text { qoq credit growth } \\
\text { is larger than } 6 \\
\text { percent (and loan } \\
\text { book big enough) }\end{array}$ & $\begin{array}{l}\text { Yes. Increase in } \\
\text { RR in } 04: \mathrm{Q} 4 \text { and } \\
\text { LCP in } 05: \mathrm{Q} 2\end{array}$ & $\begin{array}{l}\text { Yes. CAP } \\
\text { measures in } \\
05: Q 3 \text { and } \\
\text { increase in } \\
\text { penalties in } 05: Q 4\end{array}$ & -5.7 & -1.6 \\
\hline LCP & $\begin{array}{l}\text { Loan } \\
\text { classification }\end{array}$ & Bulgaria & 05:Q2 & $\begin{array}{l}\text { No migration } \\
\text { back to lower risk } \\
\text { category category } \\
\text { for restructured } \\
\text { exposures before } \\
6 \text { months }\end{array}$ & $\begin{array}{l}\text { Yes. Increase in } \\
\text { RR in 04:Q4 and } \\
\text { ARR in } 05: Q 2\end{array}$ & $\begin{array}{l}\text { Yes. CAP } \\
\text { measures in } \\
05: Q 3 \text { and } \\
\text { increase in } \\
\text { penalties in } 05: Q 4\end{array}$ & -5.7 & -1.6 \\
\hline CAP & RW HH & Bulgaria & 05:Q3 & $\begin{array}{l}\text { Increase in risk- } \\
\text { weights on high- } \\
\text { LTV mortgage } \\
\text { loans }\end{array}$ & $\begin{array}{l}\text { Yes. Credit ceiling } \\
\text { since } 05: Q 2 \text {, } \\
\text { capital eligibility } \\
\text { measure in } 05: \text { Q3 }\end{array}$ & $\begin{array}{l}\text { Yes. Increase } \\
\text { in credit ceiling } \\
\text { penalties in } 05: \mathrm{Q}^{4}\end{array}$ & -6.0 & -3.0 \\
\hline CAP & $\begin{array}{l}\text { Capital } \\
\text { eligibility }\end{array}$ & Bulgaria & 05:Q3 & $\begin{array}{l}\text { Exclusion of } \\
\text { interim profits } \\
\text { from capital base }\end{array}$ & $\begin{array}{l}\text { Yes. Credit ceiling } \\
\text { since } 05: Q 2, \\
\text { RW measure in } \\
05: Q 3\end{array}$ & $\begin{array}{l}\text { Yes. Increase } \\
\text { in credit ceiling } \\
\text { penalties in } 05: \mathrm{Q} 4\end{array}$ & -4.8 & -1.6 \\
\hline ARR & Credit ceiling & Bulgaria & $05: Q^{4}$ & $\begin{array}{l}\text { Increase in } \\
\text { penalty rate (up to } \\
400 \text { percent) }\end{array}$ & $\begin{array}{l}\text { Yes. Credit ceiling } \\
\text { since } 05: \mathrm{Q} 2 \text {, } \\
\text { CAP measures in } \\
05: \mathrm{Q} 3 \text {, and LCP } \\
\text { measure in } 05: \mathrm{Q} 4\end{array}$ & $\begin{array}{l}\text { Yes. RW measure } \\
\text { in } 06: \mathrm{Q} 2\end{array}$ & -3.6 & -1.6 \\
\hline
\end{tabular}

11 The methodology used to assess effectiveness with respect to the other two targets (share of foreign currency lending, and share of foreign borrowing) is as follows. We deem a measure targeting FC lending and implemented in period $t$ to be effective if the change in the trend of the share of FC lending in total lending around $t$ has the right sign and is "significant". The trend "before" is the difference between the share of FC lending at time $t$ and that at time $t-2$, and the trend "after" is the difference between the share of FC lending at time $t+2$ and that at time $t$. We use the same approach for the share of foreign borrowing. 


\begin{tabular}{|c|c|c|c|c|c|c|c|c|}
\hline Type & Instrument & Country & Quarter & Details & $\begin{array}{l}\text { Reinforcing } \\
\text { nature }\end{array}$ & $\begin{array}{l}\text { Reinforcing } \\
\text { measures soon } \\
\text { afterwards }\end{array}$ & $\begin{array}{l}\text { Change } \\
\text { in credit } \\
\text { growth }\end{array}$ & Threshold \\
\hline LCP & $\begin{array}{l}\text { Provisioning } \\
\mathrm{HH}\end{array}$ & Bulgaria & 05:Q4 & $\begin{array}{l}\text { Increase in } \\
\text { provisioning } \\
\text { rates for loans } \\
\text { to households }\end{array}$ & $\begin{array}{l}\text { Yes. Credit } \\
\text { ceiling since } \\
\text { 05:Q2, tightened } \\
\text { in 05:Q4, } \\
\text { CAP measures } \\
\text { in 05:Q3 }\end{array}$ & $\begin{array}{l}\text { Yes. RW measure } \\
\text { in } 06: \mathrm{Q} 2\end{array}$ & -6.4 & -3.0 \\
\hline ARR & Credit ceiling & Croatia & 03:Q1 & $\begin{array}{l}\text { Requirement to } \\
\text { buy low-yielding } \\
\text { central bank } \\
\text { bills if qoq credit } \\
\text { growth is larger } \\
\text { than } 4 \text { percent }\end{array}$ & $\begin{array}{l}\text { Yes. FCLR } \\
\text { measure in 03:Q1 }\end{array}$ & No & -3.6 & -0.4 \\
\hline ARR & Credit ceiling & Croatia & 07:Q1 & $\begin{array}{l}\text { Requirement to } \\
\text { buy low-yielding } \\
\text { central bank bills } \\
\text { if annual credit } \\
\text { growth is larger } \\
\text { than } 12 \text { percent }\end{array}$ & $\begin{array}{l}\text { Yes. Earlier } \\
\text { MRR and SRR } \\
\text { measures, FCLR } \\
\text { measure in 06:Q4, } \\
\text { RW and LCP } \\
\text { measures in } 06\end{array}$ & No & -2.5 & -0.4 \\
\hline ELI & $\begin{array}{l}\text { LTV, DSTI on } \\
\text { HH }\end{array}$ & Romania & 04:Q1 & $\begin{array}{l}\text { Introduction of } \\
\text { LTV and DSTI }\end{array}$ & No & No & -25.8 & -9.0 \\
\hline LRR & $\begin{array}{l}\text { RR FC, RR } \\
\text { Foreign } \\
\text { borrowing }\end{array}$ & Serbia & 06:Q2 & $\begin{array}{l}\text { Increase in RR } \\
\text { FC rate and } \\
\text { expansion of the } \\
\text { base }\end{array}$ & $\begin{array}{l}\text { Yes. Net } \\
\text { tightening } \\
\text { of reserve } \\
\text { requirements } \\
\text { in } 05\end{array}$ & $\begin{array}{l}\text { Yes. Introduction } \\
\text { of } \mathrm{HH} \text { leverage } \\
\text { ratio in } 06: \mathrm{Q} 3 \text { and } \\
\text { higher RW FC in } \\
06: \mathrm{Q} 4\end{array}$ & -4.6 & -0.5 \\
\hline CAP & $\begin{array}{l}\text { Sectoral } \mathrm{HH} \\
\text { leverage ratio }\end{array}$ & Serbia & 07:Q3 & $\begin{array}{l}\text { Extension of the } \\
\text { scope of the } \\
\text { regulation } \\
\text { to include all } \\
\text { housing loans }\end{array}$ & $\begin{array}{l}\text { Yes. Sectoral } \\
\text { leverage ratio } \\
\text { introduced } \\
\text { in 06:Q3 and } \\
\text { penalties } \\
\text { increased in } \\
07: Q 2 \text {, } \\
\text { Higher RW FC } \\
\text { in 06:Q4 }\end{array}$ & $\begin{array}{l}\text { Yes. Tightening of } \\
\text { the ratio in } 07: \mathrm{Q} 4\end{array}$ & -5.1 & -4.7 \\
\hline
\end{tabular}

$\mathrm{ARR}=$ asset-based reserve requirements, $\mathrm{LRR}=$ liability-based reserve requirements and liquidity ratios, $\mathrm{CAP}=$ capital regulation, $\mathrm{LCP}=$ loan classification and provisioning rules. $\mathrm{HH}=$ household.

Shaded rows indicate those measures that were found effective in slowing household credit growth. In Bulgaria, these measures on household credit took place at the same time as other tightening measures, and therefore likely reinforced each other (orange shading), while in Romania and Serbia, we did not identify any reinforcing measures that took place concurrently (blue shading).

Source: Authors' calculations.

\subsection{ARR measures slowed down domestic credit growth while they were in place}

The experience of Bulgaria and Croatia suggests that ARRs can help restrain domestic credit growth when they are binding and the marginal reserve requirement rates are very high.

The ARR measures in Bulgaria - which had an initial rate of 200 percent if quarterly credit growth exceeded 6 percent - helped reduce the growth of credit to the private sector while they were in place in 2005-06. When they were relaxed, and later abandoned upon EU accession in 2007, credit growth picked up again strongly (Figure 3, top chart). The effect of pre-announcing the ARR is evident: in the first quarter of 2005, banks raced to build up their loan books to increase the base from which the credit ceiling would be applied, and a pronounced kink is observed during 
that period. ${ }^{12}$ Once the ceiling became implemented and binding in 2005:Q2, credit growth fell back. However, because a tightening LCP measure was taken concurrently (Figure 3, bottom chart), we cannot attribute fully the slowdown to the ARR measure. Similarly, the increase in the penalty rate later in 2005 happened together with further LCP tightening and followed a RW tightening, so the persistence of the domestic credit slowdown cannot be cleanly attributed to the ARR measure. Following the penalty reduction in 2006:Q3, credit growth accelerated, a reversal which may have been reinforced by the removal of the earlier LCP measure.

The so-called credit growth reserve was imposed in Croatia in 2003:Q1 (with a quarterly credit growth threshold of 4 percent and a penalty rate of 200 percent), was abandoned one year later, and reinstated in 2007:Q1 (with a stricter credit growth threshold of 12 percent annually, but a lower penalty rate of 50 percent). In both instances (Figure 4, top chart), credit growth slowed down. In the second instance, the penalty was likely deemed insufficient, as credit growth rebounded in 2008:Q1, which led the authorities to increase the penalty to 75 percent. Credit growth resumed its decline but this was soon compounded by the effects of the GFC, making any effectiveness assessment moot. In both instances, a LRR measure (tightening in the FCLR) took place in a nearby period, suggesting a possible reinforcing role of the measure in making it costlier to expand credit as foreign currency liquidity requirements were tightened. However, we do not find that these FCLR measures had any significant impact on the evolution of the share of foreign currency lending (using the methodology explained in footnote 11) and therefore they do not qualify as effective. Credit growth increased only several quarters after the first credit growth reserve was abandoned. Credit growth did not increase after the second credit growth reserve was abandoned either, as the measure was no longer binding at this point in the cycle.

\subsection{LRR measures generally had no significant effect on domestic credit growth, except at the peak of the tightening cycle in Serbia}

The effect of liability-based reserve requirements and liquidity requirement measures on domestic credit growth appears mixed at best. Policy tightening in Bulgaria (i.e. increasing the rate of reserve requirements up to 12 percent, or expanding their base) did not slow down credit growth during the boom, while small easing measures (e.g. the RR rate on domestic deposits was cut by only 2 pps) were not followed by a rebound in credit growth during the bust (Figure 3 , middle chart). In Croatia, the RR measures were of very small magnitude and aren't associated with a significant movement in credit growth in the right direction in the two quarters following implementation (Figure 4, middle chart). The FCLR measures (a net tightening resulting from a reduction in the rate by 18 pps combined with an extension of the base in 2003:Q1, and the inclusion of FC-indexed liabilities in the base in 2006:Q4) mentioned in the paragraph above are, but do not meet our effectiveness criterion. In Romania, neither the increase in the rate of reserve requirement on FC liabilities (which peaked at 40 percent in 2006) nor the broadening of the base were followed by a credit growth slowdown during the boom (Figure 5, top chart). During the bust period, marginal easing of reserve requirements was not followed by any significant increase in credit growth.

The same diagnostic of ineffectiveness is generally true for Serbia, (Figure 6, top chart), although some effect can be observed at the peak of the tightening cycle: in 2006:Q2 credit growth slowed when the reserve requirement rate on FC deposits reached 40 percent, and the rate on short-term external borrowing reached 60 percent. After the first easing measure was taken later that year - a reduction of the reserve requirement rate on domestic currency deposits from 18 percent to 15 percent, which was taken concurrently with a reduction in the policy rate for monetary policy reasons in the context of the introduction of the so-called New Monetary Policy

12 To account for this effect, we replace credit growth in 2005:Q1 and 2005:Q2 by their average. 
Framework, not for macroprudential reasons - credit growth rebounded and the credit-to-GDP ratio resumed its upward trend. Frequent adjustments of LRRs - although with a tightening bias suggest that calibration was difficult during the boom. Successive easing measures (a reduction of the base, a 5 pps rate cut on the domestic currency base, a 15 pps rate cut on the foreign currency base) during the bust period were not followed by a revival of domestic credit growth.

Figure 3.

Bulgaria: Domestic Credit to Private Sector, 2001:Q4-2012:Q4 (Exchange-rate-adjusted QoQ growth rate and ratio to GDP, in percent)
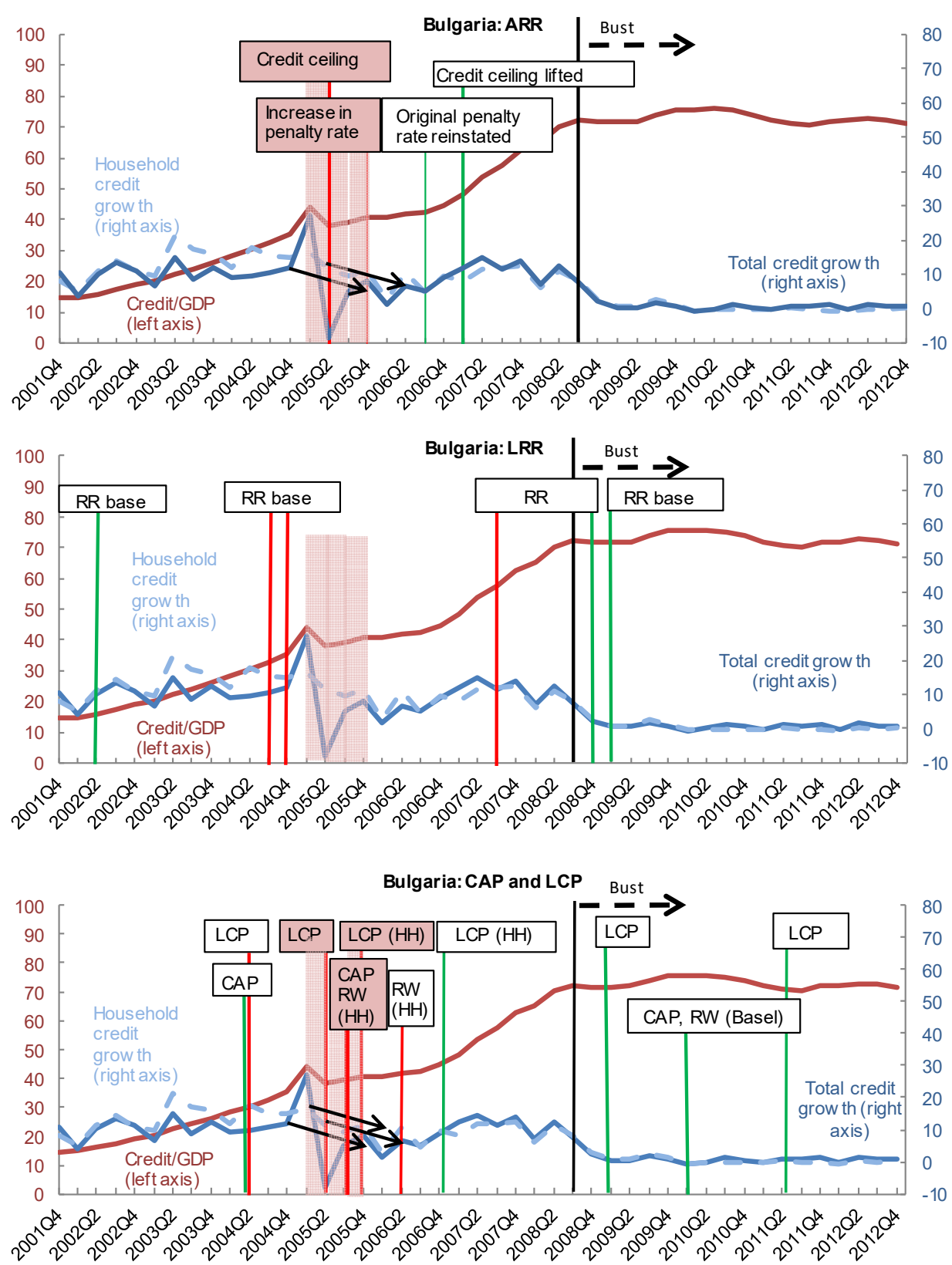

Notes: a green line indicates policy loosening, a red line indicates policy tightening, and a yellow line indicates both loosening and tightening in the same quarter. Shaded text indicates effectiveness. Shaded areas indicate quarters when a measure deemed effective was implemented.

$\mathrm{ARR}=$ asset-based reserve requirements, $\mathrm{LRR}=$ liability-based reserve requirements and liquidity ratios, $\mathrm{CAP}=\mathrm{capital}$ regulation, $\mathrm{LCP}=$ loan classification and provisioning rules.

See Appendix 2 for a full description of the measures.

Sources: Vandenbussche et al. (2015), central bank websites and publications, International Financial Statistics (IFS), and authors' calculations. 
Figure 4.

Croatia: Domestic Credit to Private Sector, 2001:Q4-2012:Q4 (Exchange-rate-adjusted QoQ growth rate and ratio to GDP, in percent)
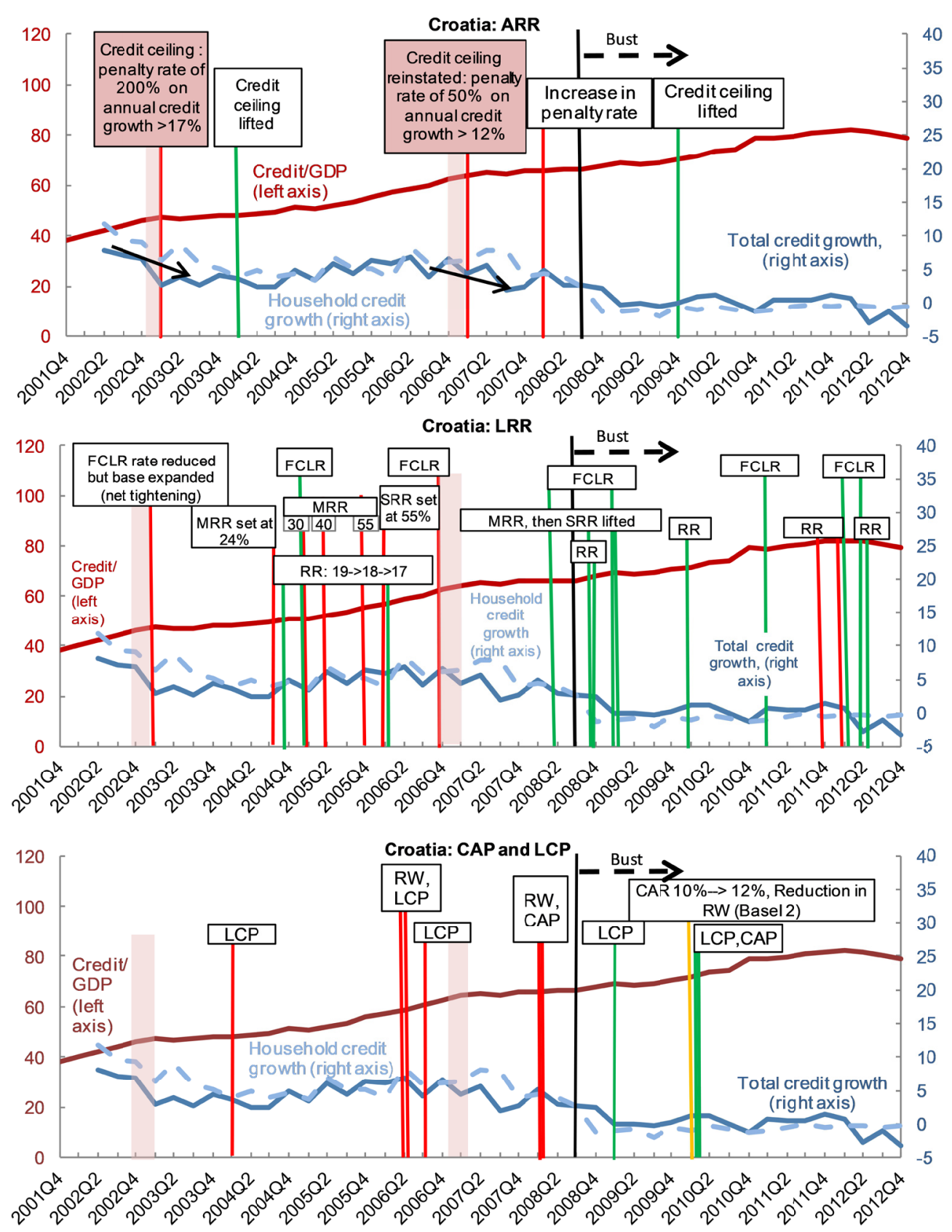

Notes: a green line indicates policy loosening, a red line indicates policy tightening, and a yellow line indicates both loosening and tightening in the same quarter. Shaded text indicates effectiveness. Shaded areas indicate quarters when a measure deemed effective was implemented. $\mathrm{ARR}=$ asset-based reserve requirements, $\mathrm{LRR}=$ liability-based reserve requirements and liquidity ratios, $\mathrm{CAP}=$ capital regulation, $\mathrm{LCP}=$ loan classification and provisioning rules.

See Appendix 2 for a full description of the measures.

Sources: Vandenbussche et al. (2015), central bank websites and publications, International Financial Statistics (IFS), and authors' calculations. 
Figure 5.

Romania: Domestic Credit to Private Sector, 2001:Q4-2012:Q4 (Exchange-rate-adjusted QoQ growth rate and ratio to GDP, in percent)
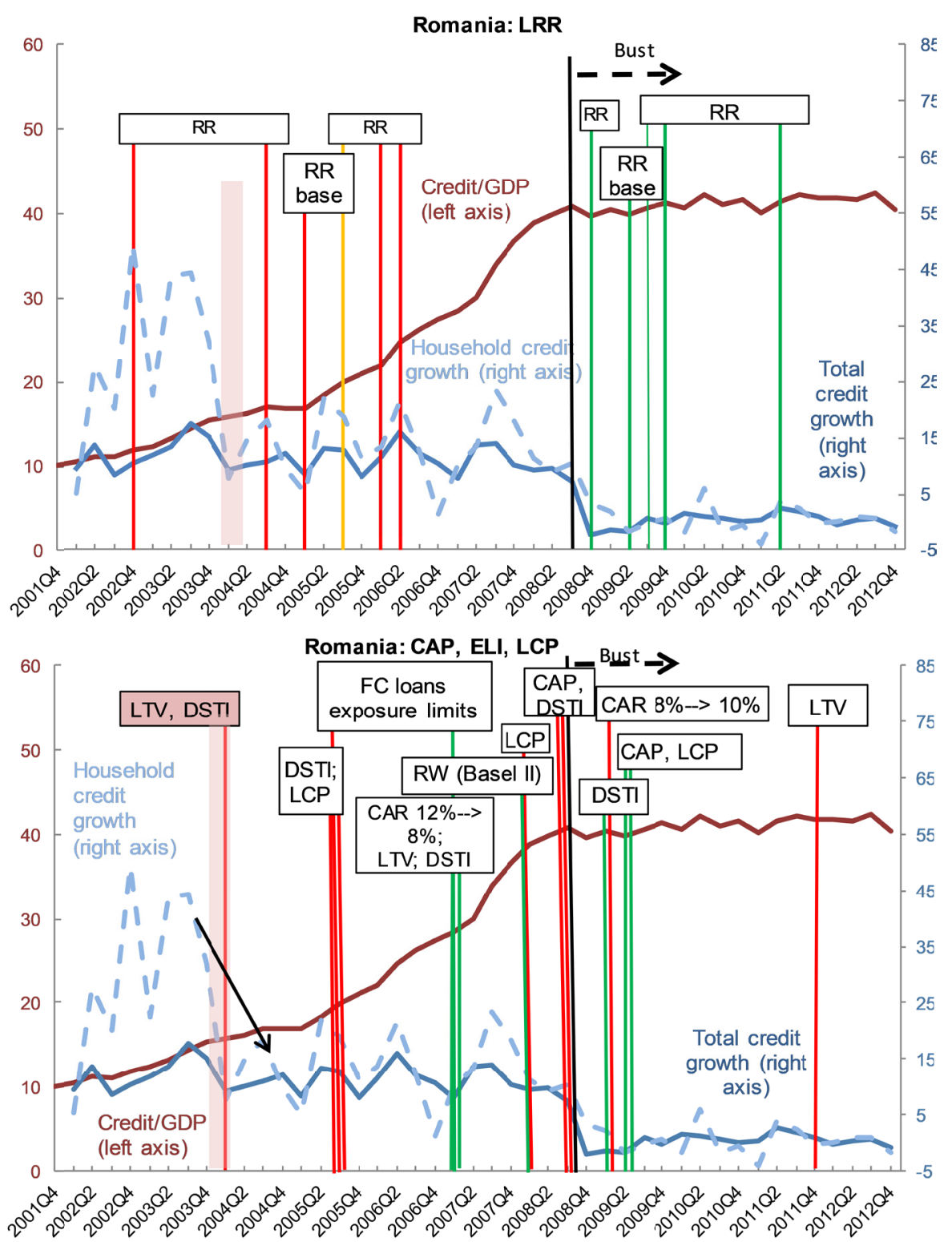

Notes: a green line indicates policy loosening, a red line indicates policy tightening, and a yellow line indicates both loosening and tightening in the same quarter. Shaded text indicates effectiveness. Shaded areas indicate quarters when a measure deemed effective was implemented.

$\mathrm{CAP}=$ capital regulation, $\mathrm{LCP}=$ loan classification and provisioning rules, $\mathrm{LRR}=$ liability-based reserve requirements and liquidity ratios, $\mathrm{ELI}=$ eligibility requirements. $\mathrm{FC}=$ foreign currency; $\mathrm{LC}=$ domestic currency; $\mathrm{HH}=$ household See Appendix 2 for a full description of measures.

Sources: Vandenbussche et al. (2015), central bank websites and publications, International Financial Statistics (IFS), and authors' calculations. 
Figure 6.

Serbia: Domestic Credit to Private Sector, 2001:Q4-2012:Q4 (Exchange-rate-adjusted QoQ growth rate and ratio to GDP, in percent)
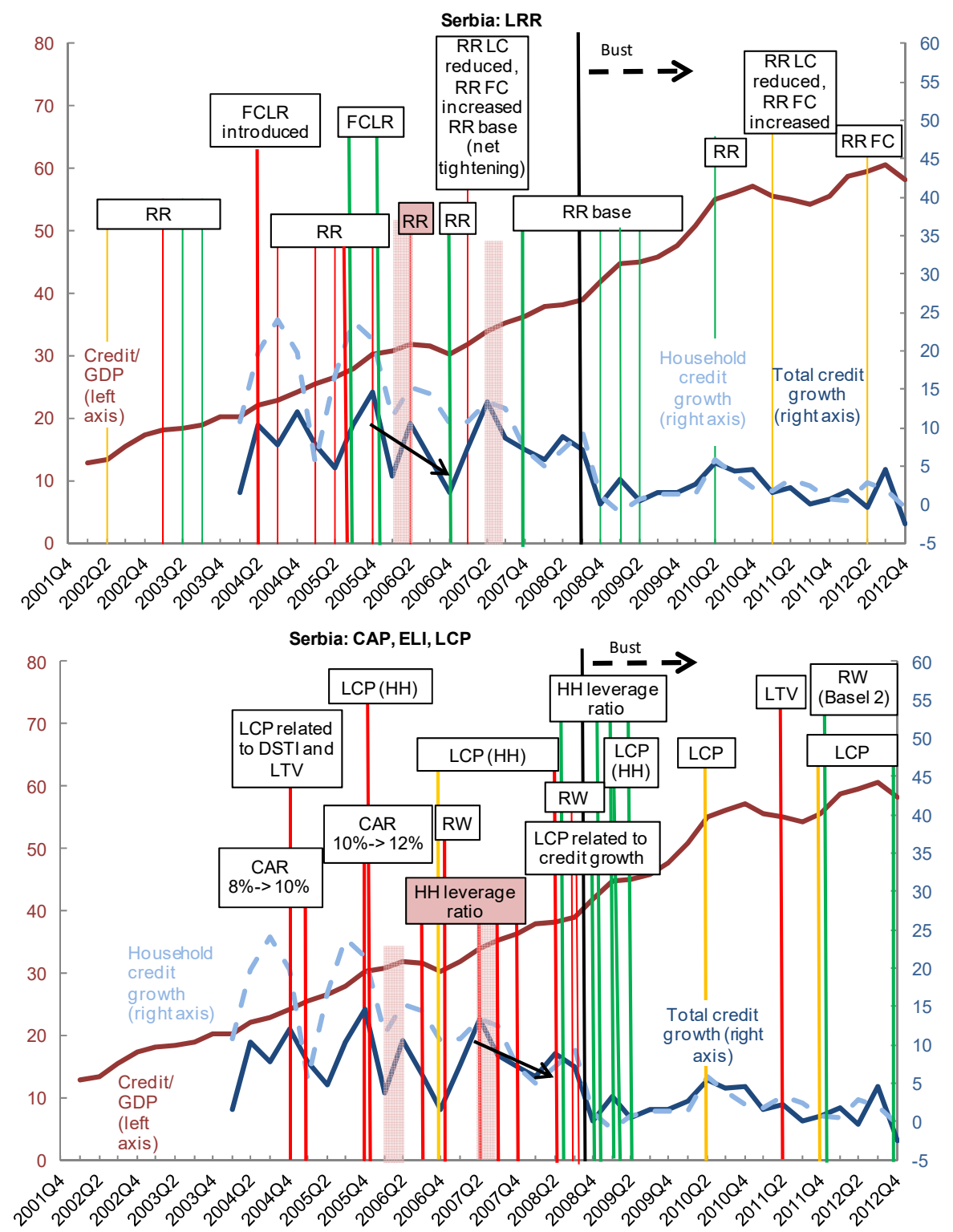

Notes: a green line indicates policy loosening, a red line indicates policy tightening, and a yellow line indicates both loosening and tightening in the same quarter. Shaded text indicates effectiveness. Shaded areas indicate quarters when a measure deemed effective was implemented.

$\mathrm{CAP}=$ capital regulation, $\mathrm{LCP}=$ loan classification and provisioning rules, $\mathrm{LRR}=$ liability-based reserve requirements and liquidity ratios, $\mathrm{ELI}=$ eligibility requirements. $\mathrm{FC}=$ foreign currency; $\mathrm{LC}=$ domestic currency; $\mathrm{HH}=$ household .

See Appendix 2 for a full description of measures.

Sources: Vandenbussche et al. (2015), central bank websites and publications, International Financial Statistics (IFS), and authors' calculations.

\subsection{Some strong sectoral CAP measures were effective at curbing credit to households during the boom}

A household credit growth slowdown took place in Bulgaria around the time when risk-weights on mortgages were increased from 50 percent to 100 percent for loans with an LTV in excess of 70 percent in 2005:Q3 (Figure 3, bottom panel). The effect of that measure was very likely reinforced by the ARR measures taken right before and right after, and by the exclusion of current profits from the regulatory capital base taken in the same quarter, but the decline in household credit growth was stronger than the decline in total credit growth ( -6 percent versus -4.8 percent), suggesting that the measure had an impact over and above that of the other non-sectoral measures 
taken concurrently. A further increase of mortgage risk-weights is not associated with a further slowdown, but the effect of the measure was blurred by the easing of the credit ceilings soon after.

Serbia's use of a sectoral leverage ratio helped decrease household credit growth in the second half of 2007, once the initial measure was tightened by broadening the base (Figure 6, bottom panel). Loans to households were originally capped at 200 percent of share capital in 2006:Q3, with some exceptions (e.g. for loans for housing construction supported by the government), with the cap later tightened to 150 percent of share capital and the exceptions removed in 2007:H2. The effect of this measure was reinforced by an increase in penalties for non-compliance earlier in the year and by lowering the leverage ceiling during the following quarter. The chart suggests that the latter was effective too, but it took place too close to the onset of the GFC to be properly assessed using our methodology. The sectoral leverage ratio was loosened and then abandoned relatively soon into the bust period in 2009. Its removal had no visible impact on household credit growth.

Other CAP measures did not have a significant effect on total private sector credit growth or household credit growth in any of the four countries (Figures 3-6, bottom panels). We note, however, that the reduction in the minimum CAR from 12 percent to 8 percent (taken concurrently with an easing of ELI measures) in Romania was followed by to a steeper increase in the creditto-GDP ratio.

\subsection{Early ELI measures in Romania helped curb household credit growth during the boom}

Only Romania used ELI measures during the boom. The introduction of LTV (75 percent) and DSTI ceilings (30 percent of net income for consumer credit and 35 percent for mortgage credit) weakened household credit growth after their introduction in 2004:Q1 (Figure 5, bottom panel), although the level remained very high (above 10 percent QoQ) afterwards. Surprisingly, the tightening of DSTI in 2005:Q3 does not seem to have led to a further reduction. During the bust, the reintroduction of LTV limits by currency ( 85 percent for domestic currency loans, 75 percent for loans in euros, and 60 percent for loans in another currency) had no significant impact. Neither did their introduction in Serbia (LTV of FC-denominated and indexed mortgage loans capped at 80 percent in 2011:Q2).

\subsection{LCP measures generally had no significant effect on domestic credit growth, except perhaps in Bulgaria when taken concurrently with other measures}

Though both broad-based LCP (in 2005:Q2) and sectoral LCP (in 2005:Q4) measures in Bulgaria seem effective, they took place concurrently with credit ceilings measures. The broadbased measure was too weak - a lengthening to six months of the time required for restructured exposures to migrate to a lower risk category - to have been a reason to cut credit supply. The sectoral LCP measure was concurrent with a tightening of credit ceilings and implemented shortly after risk-weights on mortgages were increased. Minimum specific provisions to cover impairment loss were raised from 10 to 20 percent for so-called watch exposures and from 50 to 75 percent for so-called substandard exposures. This measure may have had a reinforcing effect but is unlikely to have been sufficiently strong to have a significant impact by itself.

\section{CIRCUMVENTION VIA CROSS-BORDER LENDING}

This section examines further evidence to assess whether our claim that some strong measures were effective has to be qualified owing to circumvention. Circumvention is analyzed through cross-border lending only, as data on lending by domestic nonbanks is not sufficiently available. Also for lack of availability of more granular data, the focus is on credit to the private sector as 
a whole. ${ }^{13}$ For this reason, we do not examine the circumvention of measures specifically targeting household lending. The analysis covers cross-border credit from all types of lenders as reported in countries' external debt positions (sourced from IFS), and the sub-component consisting only in cross-border credit from BIS-reporting banks (sourced from the BIS). Overall, we find that circumvention offset to a considerable extent the effectiveness of the strictest measures.

\section{Figure 7.}

Bulgaria, Croatia, and Serbia: Credit Growth Measures Circumvention, 2001:Q4-2012:Q4 (private sector credit to GDP, in percent)
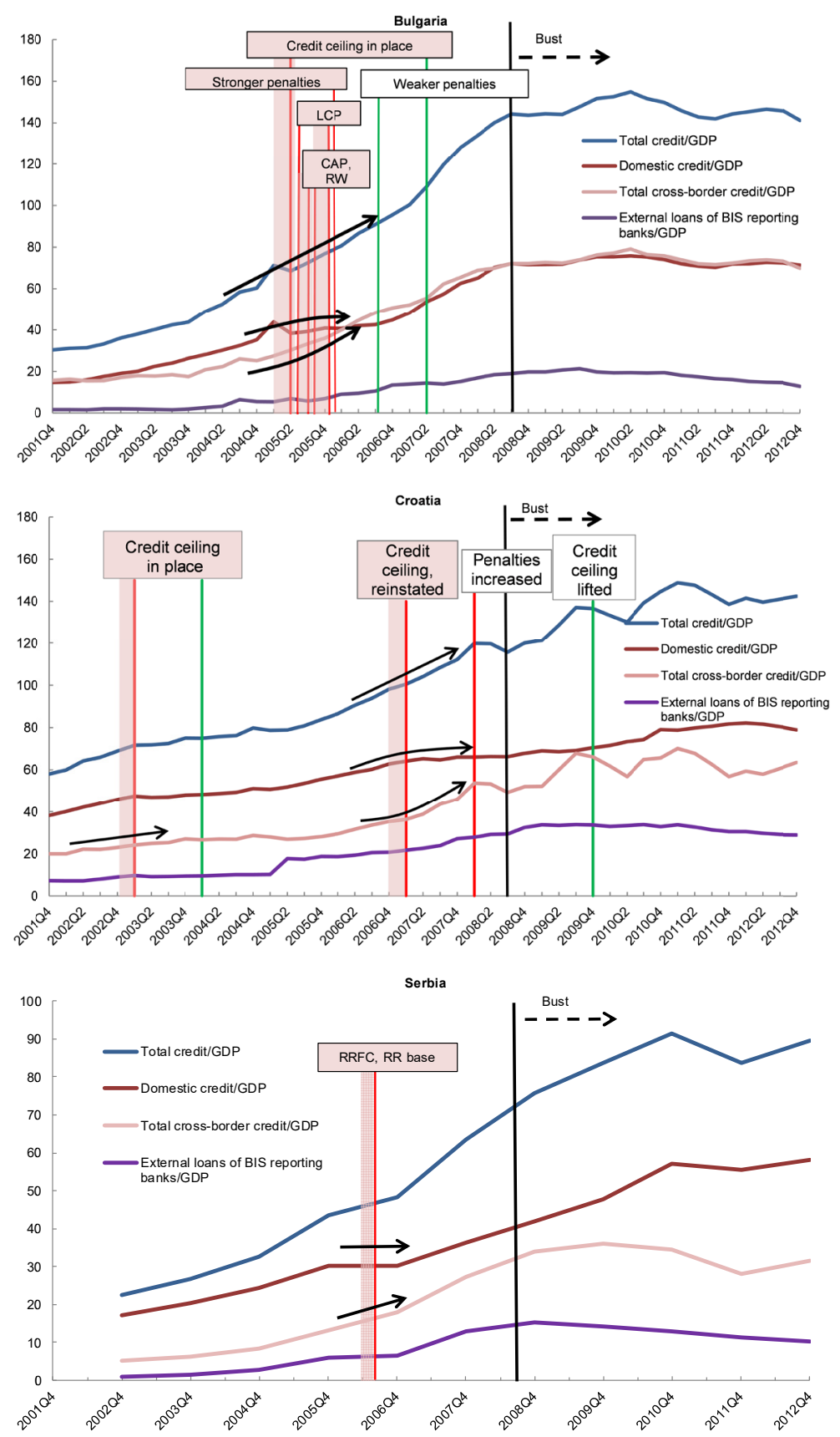

Notes: a green (resp. red) solid line indicates a loosening (resp. tightening). Shaded text and areas indicate effectiveness. LCP $=$ loan classification and provisioning; $\mathrm{CAP}=$ capital regulation; $\mathrm{RW}=$ risk-weights; $\mathrm{RR}=$ reserve requirements; $\mathrm{RRFC}=$ reserve requirements in foreign currency. See Appendix 2 for a full description of measures.

Sources: Vandenbussche et al. (2015), central bank websites and publications, International Financial Statistics (IFS), BIS, and authors' calculations.

13 However, we note that cross-border lending to households is likely to have been very limited. 
The previous section showed that ARR measures as well as two CAP measures and possibly one LCP measure had been effective in restraining domestic credit growth in Bulgaria from 2005. Looking now at the dynamics of the sum of domestic and cross-border lending, one can see that it remained broadly unchanged after the implementation of those measures as cross-border credit accelerated at the same time (Figure 7, top panel). In Croatia, a similar pattern can be observed when the credit growth ceiling was implemented for the second time from 2007:Q1 (Figure 7, middle panel). However, there is no evidence of circumvention during the first credit growth ceiling episode in 2003, perhaps reflecting the fact that the boom in the region was still nascent (and push factors not quite as powerful as they would become later on) and that the credit growth ceiling was looser in 2003 (4 percent quarterly) than in 2007 (12 percent annually). In both Bulgaria and Croatia, the shift by the private sector from domestic borrowing to cross-border borrowing was not a mere artefact of accounting changes by large (BIS-reporting) international banking groups, that is, of the predominance of foreign-owned banks in the domestic market that could have easily booked loans to local customers outside of their local bank subsidiary. In fact, the acceleration in lending by BIS-reporting banks to the private sector remained relatively modest. The large degree of circumvention likely reflected a deep financial integration of both economies with that of the EU. ${ }^{14}$ By contrast, Serbia was relatively less integrated with the EU at the time (it was not an accession candidate). This may explain why the growth in cross-border lending did not fully offset the cooling effect of strong LRR measures on domestic credit growth in 2006 (Figure 7, bottom panel).

\section{CONCLUSION}

This paper has documented that macroprudential measures helped contain domestic credit growth during the boom of the mid-2000s in CESEE only if they were strong. Specifically, the analysis uncovered that during the boom period: (1) binding marginal reserve requirements related to credit growth ("credit growth ceilings") helped contain domestic credit growth; (2) strong sectoral capital measures and (3) the introduction of meaningful loan-to-value and debt-serviceto-income ceilings helped limit household credit growth. However, circumvention via direct external borrowing largely offset the direct effect, particularly of measure (1). A corollary finding is that none of the other, less strict measures (the vast majority) met our criterion for effectiveness. In a few cases, less-immediately-binding loan classification and provisioning measures were taken concurrently with the strong measures we deem effective and may have reinforced their effect. Measures taken during the subsequent bust had no discernible impact.

Based on these findings, we conclude that weak-to-moderate measures are likely to lack any bite. Strong measures can be more successful in containing credit booms but their impact is likely to be offset by various forms of circumvention. Restricting these channels of circumvention from the start should be an integral part of policy design and is likely to require strong international cooperation.

Our analysis ends in 2012. Looking forward, circumvention through cross-border bank borrowing is likely to be constrained, at least to some extent, by the design of Basel III's countercyclical capital buffer (CCyB), which was introduced in recent years. ${ }^{15}$ According to the Basel III framework, national macroprudential authorities set the level of the CCyB, and international reciprocity is mandatory for $\mathrm{CCyBs}$ up to 2.5 per cent (and voluntary above 2.5 percent). Only time will tell whether the calibration of the Basel III CCyB reciprocity parameters is adequate for emerging economies such as Bulgaria, Croatia, Romania and Serbia. In any case, our findings suggest that measures with a broader base - including capital flows

14 Croatia became an EU accession candidate in 2004, and accession negotiations began in 2005.

15 Basel III was implemented in 2014 in the European Union, and in 2016 in Serbia. 
management measures targeting nonbank flows - would have been needed to contain overall credit growth in these four economies.

The analysis also carries lessons for future research. The relationship between the strength of a macroprudential policy measure and its effect on an intermediate policy objective such as credit growth appears to be non-linear in nature. Measures seem to have a visible effect only above a certain threshold, and the effects of tightening and easing are likely asymmetric. Furthermore, the effect of macroprudential policies seem to differ between booms and busts. To speak to the key issue of instrument calibration, future econometric studies of effectiveness should allow for these non-linear and state-contingent effects.

\section{Acknowledgements}

We would like to thank two anonymous referees as well as participants at the 2016 IFABS conference and at a seminar at the IMF.

\section{References}

Aiyar S., Calomiris C., Wieladek T. (2014) Does Macro-Prudential Regulation Leak? Evidence from a UK Policy Experiment. Journal of Money, Credit and Banking, Vol. 46, Issue S1, pp. 181-214.

Ahuja A., Nabar M. (2011) Safeguarding Banks and Containing Property Booms: Cross-Country Evidence on Macroprudential Policies and Lessons from Hong Kong SAR. International Monetary Fund Working Paper No. 11/284.

Bakker B., Klingen C. (2012). How Emerging Europe Came Through the 2008/09 Crisis: An Account by the Staff of the IMF's European Department, Washington D.C.

Banai A., Király J., Nagy M. (2011) Home High Above and Home Deep Down Below - Lending in Hungary. World Bank Policy Research Working Paper No. 5836.

Celeska F, Gligorova V., Krstevska A. (2011) Macroprudential Regulation of Credit Booms and Busts - The Experience of the National Bank of the Republic of Macedonia. World Bank Policy Research Working Paper No. 5770.

Cerutti E., Claessens S., Laeven L. (2015) The Use and Effectiveness of Macroprudential Policies: New Evidence. International Monetary Fund Working Paper No. 15/61.

Claessens S., Ghosh S., Mihet R. (2013) Macro-Prudential Policies to Mitigate Financial System Vulnerabilities. Journal of International Money and Finance, 39(155), pp. 153-185.

Claessens S. (2015) An Overview of Macroprudential Policy Tools. Annual Review of Financial Economics, Vol. 7, pp. $397-422$

Claessens S., Van Horen N. (2015) The impact of the global financial crisis on banking globalization. IMF Economic Review, Vol. 63, Issue 4, pp. 868-918.

Cottarelli C., Dell'Ariccia G., Vladkova-Hollar I. (2005) Early Birds, Late Risers, and Sleeping Beauties: Bank Credit Growth to the Private Sector in Central and Eastern Europe and in the Balkans. Journal of Banking and Finance, Vol. 29, Issue 1, pp. 83-104.

Dassatti Camors C., Peydro J.-L. (2014) Macroprudential and Monetary Policy: Loan-Level Evidence from Reserve Requirements. mimeo, Universitat Pompeu Fabra, Spain.

Dell'Ariccia G., Igan D., Laeven L., Tong H., with Bakker B. and Vandenbussche J. (2012) Policies for Macrofinancial Stability: How to Deal with Credit Booms. International Monetary Fund Staff Discussion Note 12/06.

Dimova D., Kongsamut P., Vandenbussche J. (2016) Macroprudential Policies in Southeastern Europe. International Monetary Fund Working Paper No. 16/29.

Enoch C., Ötker-Robe I. (2007) Rapid Credit Growth in Central and Eastern Europe: Endless Boom or Early Warning? Hampshire and New York, Palgrave Macmillan.

European Systemic Risk Board (2011) Recommendation of the European Systemic Risk Board. of 22 December 2011 on the Macroprudential Mandate of National Authorities (ESRB/2011/3).

Galac T. (2010) The Central Bank as Crisis Manager in Croatia - A Counterfactual Analysis. Croatian National Bank Working Paper W -27.

Gersl A., Jasova M. (2014) Measures to Tame Credit Growth: Are They Effective? Economic Systems, Vol. 38, Issue 1. 
Igan D., Kang H. (2011) Do Loan-to-Value and Debt-to-Income Limits Work? Evidence from Korea. International Monetary Fund Working Paper 11/297.

International Monetary Fund (2013a) Key Aspects of Macroprudential Policy. International Monetary Fund Policy Paper.

International Monetary Fund (2013b) Key Aspects of Macroprudential Policy - Background Paper. International Monetary Fund Policy Paper.

International Monetary Fund (2014) Staff Guidance Note on Macroprudential Policy. International Monetary Fund Policy Paper.

Jacome L., Mitra S. (2015) LTV and DTI Limits - Going Granular. International Monetary Fund Working Paper $15 / 154$.

Kraft E., Galac T. (2011) Macroprudential Regulation of Credit Booms and Busts: The Case of Croatia. World Bank Policy Research Working Paper No. 5772.

Kruszka M., Kowalczyk M. (2011) Macro-Prudential Regulation of Credit Boom and Busts - the Case of Poland. World Bank Policy Research Working Paper No. 5832.

Kuttner K., Shim I. (2013) Can Non-Interest Rate Policies Stabilise Housing Markets? Evidence from a Panel of 57 Economies. Bank of International Settlements Working Paper No. 433.

Lim C.H., Columba F., Costa A., Kongsamut P., Otani A., Saiyid M., Wezel T., Wu X. (2011). Macroprudential Policy: What Instruments and How to Use Them? Lessons from Country Experiences. International Monetary Fund Working Paper No. 11/238.

Neagu F., Tatarici L., Mihai I. (2015) Implementing Loan-to-Value and Debt-Service-to-Income Measures: A Decade of Romanian Experience. National Bank of Romania Occasional Paper No. 15.

Sutt A., Korju H., Siibak K. (2011) The Role of Macro-Prudential Policies in the Boom and Adjustment Phase of the Credit Cycle in Estonia. World Bank Policy Research Working Paper No. 5835.

Tovar Mora C.E., Garcia-Escribano M., Vera Martin M. (2012) Credit Growth and the Effectiveness of Reserve Requirements and Other Macroprudential Instruments in Latin America. International Monetary Fund Working Paper No. 12/142.

Vandenbussche J., Vogel U., Detragiache E. (2015). Macroprudential Policies and Housing Prices - A New Database and Empirical Evidence for Central, Eastern, and Southeastern Europe. Journal of Money, Credit and Banking, Vol. 47, Issue S1, pp. 343-377.

Zhang L., Zoli E. (2014). Leaning Against the Wind: Macroprudential Policy in Asia. International Monetary Fund Working Paper No. 14/22. 


\section{APPENDIX 1}

1. Bulgaria, Croatia, Romania, Serbia: Selected Macro-Financial Indicators, 2002-12

\begin{tabular}{|c|c|c|c|c|}
\hline & \multicolumn{2}{|c|}{$\begin{array}{l}\text { GDP per capita } \\
\quad(\text { EUR) }\end{array}$} & \multicolumn{2}{|c|}{ Monetary Regime } \\
\hline & 2002 & 2012 & 2002 & 2012 \\
\hline Bulgaria & 2,164 & 5,489 & & \\
\hline Croatia & 6,373 & 10,115 & Managed floating & Crawl-like arrangement \\
\hline Romania & 2,196 & 6,052 & Managed floating & Floating \\
\hline \multirow[t]{3}{*}{ Serbia } & 1,586 & 3,104 & Managed floating & Floating \\
\hline & \multicolumn{2}{|c|}{$\begin{array}{l}\text { Private Sector Credit } \\
\text { (percent of GDP) }\end{array}$} & \multicolumn{2}{|c|}{$\begin{array}{c}\text { Foreign Bank Ownership } \\
\text { (percent of banking sector assets) }\end{array}$} \\
\hline & $2002^{*}$ & 2012 & 2004 & 2009 \\
\hline Bulgaria & 19 & 69 & 72 & 79 \\
\hline Croatia & 43 & 72 & 88 & 91 \\
\hline Romania & 10 & 38 & 54 & 85 \\
\hline \multirow[t]{3}{*}{ Serbia } & 19 & 51 & 61 & 75 \\
\hline & \multicolumn{2}{|c|}{$\begin{array}{l}\text { BIS-Reporting Banks' Exposures to Banks } \\
\text { (percent of GDP) }\end{array}$} & \multicolumn{2}{|c|}{$\begin{array}{l}\text { BIS-Reporting Banks' Exposures to Non-banks } \\
\text { (percent of GDP) }\end{array}$} \\
\hline & 2002 & 2012 & 2002 & 2012 \\
\hline Bulgaria & 6 & 18 & 6 & 15 \\
\hline Croatia & 15 & 32 & 13 & 32 \\
\hline Romania & 2 & 18 & 6 & 12 \\
\hline \multirow[t]{3}{*}{ Serbia } & 2 & 14 & 1 & 11 \\
\hline & \multicolumn{2}{|c|}{$\begin{array}{l}\text { Share of Private Sector Foreign Currency Deposits } \\
\text { (percent) }\end{array}$} & \multicolumn{2}{|c|}{$\begin{array}{c}\text { Share of Private Sector Foreign Currency Loans } \\
\text { (percent) }\end{array}$} \\
\hline & $2002^{*}$ & $2012^{* *}$ & $2002^{*}$ & 2012 \\
\hline Bulgaria & 54 & 44 & 42 & 63 \\
\hline Croatia & 72 & 70 & 81 & 79 \\
\hline Romania & 44 & 37 & 66 & 72 \\
\hline Serbia & 64 & 77 & 54 & 88 \\
\hline
\end{tabular}

* Data for Serbia is for 2003.

** Data for Croatia is for June 2012.

Sources: WEO, IFS, AREAER, Claessens and van Horen (2013), and IMF staff calculations. 


\section{APPENDIX 2}

This appendix describes in detail the macroprudential measures taken by the four countries during the boom and bust periods (from 2002:Q1 to 2012:Q4), grouped according to the six categories of instruments discussed in the main text (CAP = capital regulation, LCP = loan classification and provisioning rules, LRR = liability-based reserve requirements liquidity ratios, $\mathrm{ARR}=$ asset-based reserve requirements, $\mathrm{ELI}=$ eligibility requirements, $\mathrm{NBK}=$ regulation of nonbank credit institutions). It also presents a detailed chronological listing of macroprudential measures taken by country that were included in our assessment of effectiveness discussed in the main text.

\section{Use of Macroprudential Policy Instruments}

The four countries varied in their degree of interventionism. Figure A1 shows the dynamics of policy action. Generally, countries tended to tighten (red cells) the macroprudential policy stance during the boom period and loosen (green cells) during the bust period. During the boom, policymakers at times implemented various instruments simultaneously, suggesting that macroprudential authorities believed in instrument complementarity. Rarely, the intended effects would move in opposite directions (yellow cells). Some easing measures were implemented to harmonize national policies with European Union (EU) regulations ahead of EU accession (shaded cells).

During the bust, the four countries reversed some of the tightening that had taken place during the boom in order to help banks withstand the global financial crisis and help avoid a credit crunch. The most aggressive measures had become redundant and were dropped early. However, and perhaps surprisingly, some tightening during the bust also took place, in particular in the area of loan eligibility criteria. This likely reflects the realization that banks had failed to properly assess credit risk (including the exchange rate risk faced by unhedged borrowers) during the boom years and therefore that further regulatory constraints should be placed on their loan decisionmaking process. 


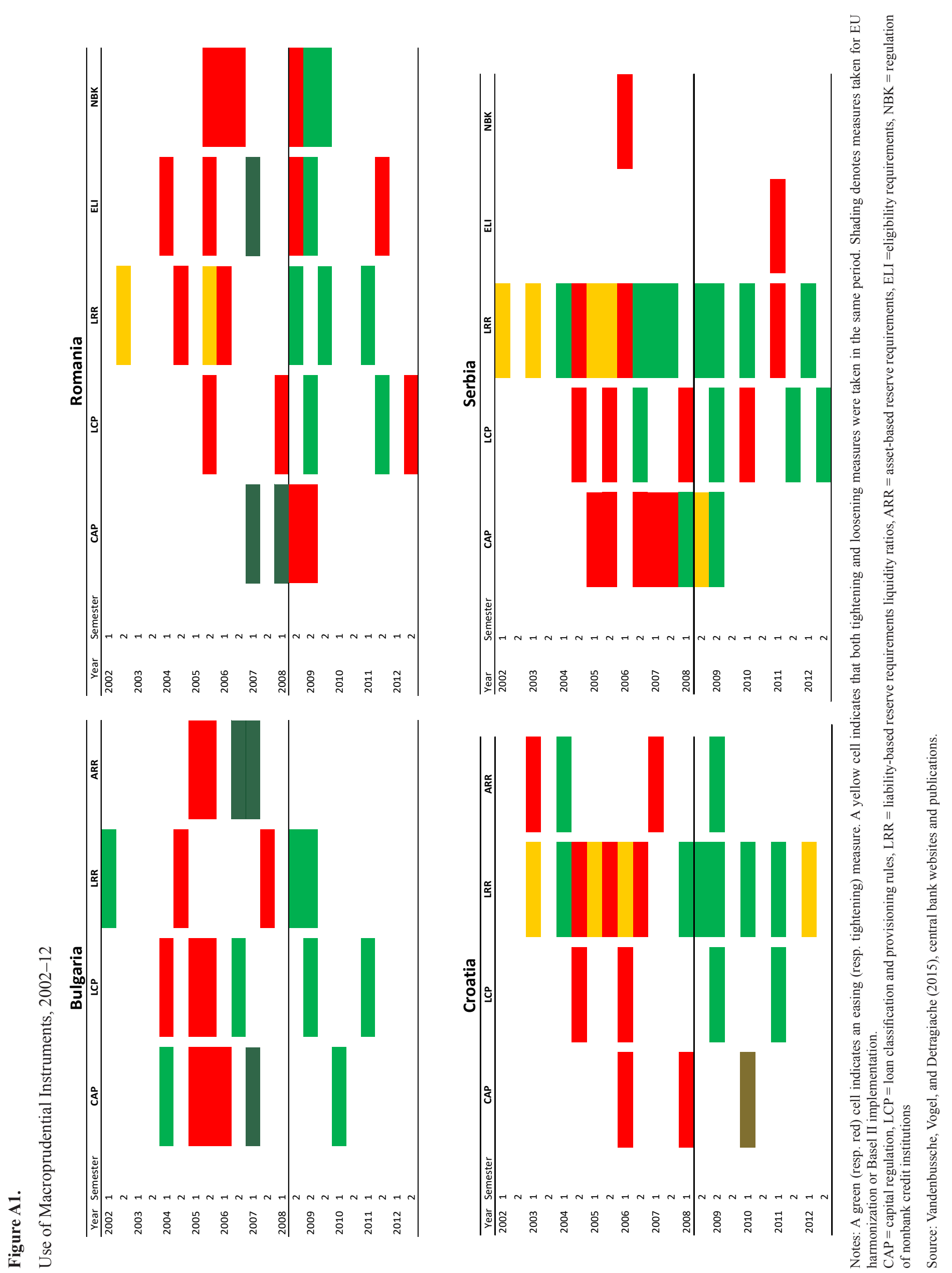




\section{Macroprudential Measures Taken during the Boom}

Countries differed in the strength of the implemented measures during the boom. Bulgaria's measures were relatively moderate, perhaps reflecting in part stricter initial conditions for the minimum capital adequacy ratio (CAR). Romania took measures to contain foreign currency (FC) exposures by tightening loan eligibility criteria and liability-based reserve requirements but scaled back loan eligibility criteria and loosened its capital regulation upon EU accession. Croatia's measures were relatively stronger, in particular in trying to curb banks' external borrowing, mainly through raising considerably liability-based reserve requirements. The focus was on slowing down banks' external debt growth and trying to manage the indirect credit risk inherent in banks' FC/FC-indexed lending through capital requirements. Serbia was the most aggressive of the four countries, tightening policies particularly in the area of capital adequacy (after starting from relatively lower minimum requirements) and liability-based reserve requirements.

\section{A. Capital Regulation (CAP)}

The following measures were adopted in the four countries:

- Changes in minimum capital adequacy ratio. Serbia increased it in two steps (from 8 percent to 12 percent) in 2005 , as the credit boom gathered pace. ${ }^{16}$ Romania reduced the minimum CAR from 12 percent to 8 percent as the country joined the EU in January 2007 and the authorities took steps to harmonize their capital regulation with that of the EU even though the measure was clearly procyclical. In contrast, Bulgaria kept the minimum 12 percent CAR upon EU accession, in part because of the still vivid memories of the domestic 1996-97 banking crisis.

- Changes in specific risk-weights $(R W)$. In response to the fast growth of mortgage lending, Bulgaria tightened risk-weights on mortgages twice (in 2005:Q3 and 2006:Q2) by making them a function of the loan-to-value (LTV) ratio. Romania also increased risk-weights on highLTV (75 percent and above) loans when it adopted Basel II in 2007:Q1. Croatia increased riskweights on foreign currency loans to unhedged borrowers twice (in 2006:Q2 and 2008:Q1) by 25 percentage points each time. While the share of FC loans and FC-indexed loans had been historically high already in Croatia, these measures seem to have been motivated in part by the rise of the share of loans indexed to the Swiss franc, the exchange rate of which against the kuna was more volatile than that against the euro. Serbia increased by 25 percentage points the risk-weights on FC and FC-indexed loans to unhedged borrowers above 10 million dinars (about $€ 100,000$ ) - effectively mostly targeting corporate loans - in 2006:Q3, then increased risk-weights on household FC loans by 25 percentage points two years later. The presence of FC-indexed loans in Croatia and Serbia most likely reflects attempts to circumvent earlier prudential measures on FC loans.

- Introduction of bank-specific minimum CAR that depend on credit growth. From January 2008, Croatia required banks to hold minimum levels of capital based on their rate of credit growth and their reliance on funding sources other than core deposits. Essentially, banks growing their loan portfolio faster than 12 percent per year had to keep their CAR above 12 percent plus 150 percent of credit growth above 12 percent.

- Introduction of specific leverage ratios. As the boom in household loans persisted in spite of measures taken in 2005, Serbia capped household lending at 300 percent of share capital from September 2006 onward and tightened the thresholds to 150 percent a year later. ${ }^{17}$ This

\footnotetext{
16 The National Bank of Serbia (NBS) explains the increase from 10 percent to 12 percent as a response to the "intensified lending activity of the banking sector" (2005 NBS Annual Report, p. 118).

17 A bank failing to meet the requirement had to make a non-remunerated deposit of twice the gap between its household lending stock and 200 percent of share capital. At the time when the measure was introduced, four banks were not compliant (2006 NBS Annual Report, p. 73).
} 
instrument was fine-tuned in several instances during its first few months of existence. ${ }^{18}$ Concerned by the fast growth of FC loans to unhedged borrowers, Romania capped the ratio of this type of loans to own funds at 300 percent from 2005:Q3 onward. However, this measure remained in place only a little more over a year as it was dropped in January 2007 when the country joined the EU.

- Exclusion of current profits from the regulatory capital base. Bulgaria excluded interim profits from the calculation of own funds in 2005:Q3, a little more than a year after having allowed their inclusion. This measure was also implemented by Romania just before the cycle turned (in 2008:Q3). ${ }^{19}$

Initial conditions of bank regulation likely played a role in the use of capital-related instruments. When Serbia increased its minimum CAR to 12 percent in 2005, it merely caught up with the other three countries which had a regulation stricter than the Basel I minimum of 8 percent already: the minimum CAR had been 12 percent in Bulgaria and Romania since 1999, and 8 percent in Croatia since 1998.

Institutional factors also played a role. While still in the acute phase of the boom, Romania lowered its minimum CAR upon joining the EU by harmonizing it with the EU minimum of 8 percent. In early 2008, it also implemented the Basel II framework as embedded in the EU's Capital Requirement Directive, which led to a reduction in risk weights for household exposures relative to the previously prevailing more conservative Basel I norms. Bulgaria took a different approach - it implemented Basel II but initially kept the Basel I risk-weights. As non-EU members Croatia and Serbia did not face similar institutional pressure. Croatia implemented Basel II from the start of 2010 while Serbia implemented it in December 2011.

Finally, initial banking sector conditions also mattered. The decision by Serbia to introduce a sectoral leverage ratio in 2006, rather than increase risk-weights on household exposures, likely reflects the fact that the CAR of Serbian banks was quite high at the time (26 percent at end2005 and 24.7 percent at end-2006) and that a constraint on credit growth through the imposition of more conservative risk-weights would not be binding enough. By emphasizing share capital (as opposed to total regulatory capital), Serbia anticipated one of the lessons of the 2008-09 global financial crisis, i.e. the importance of the quality of capital. Romania's decision to impose a similar ratio for FC exposures to unhedged borrowers also likely reflected the fact that banks had "excess" capital by the CAR metrics (20.2 percent at end-2005) and that a change in riskweights might not have been sufficiently binding. In contrast, Bulgaria had a CAR of 16.6 percent at end-2004 and of 14.6 percent at end-2006, making an increase of risk-weights more likely to be immediately effective. Similarly, the CAR in Croatia was 13.4 percent at end-2005, just before prudential authorities increased risk-weights on FC loans for the first time.

\section{B. Loan Classification and Provisioning (LCP)}

The four countries also made their loan classification and provisioning rules stricter so as to require banks to build thicker provisioning buffers and provide greater incentives for more careful loan underwriting. All countries changed the rules governing specific provisions, i.e. those provisions made against loan exposures that do not meet the criteria to belong to the safest category. Two countries also introduced a system of general provisions, i.e. provisions that are contingent neither on the characteristics nor on the performance of the loan and have built-in countercyclical features. The following measures were adopted:

\footnotetext{
18 See 2006 NBS Annual Report, p. 72

19 The exclusion was part of the BNB's "efforts to maintain banking system stability and create conditions for gradual credit growth in the economy" (BNB 2005 Annual Report, p. 39). By contrast, the National Bank of Romania (NBR) explained that the measure was "aimed at removing from the calculation of Tier 1 capital [...] the most volatile item".
} 
- Loan classification and specific provisions. Romania introduced the debtor's financial performance as a criterion for loan classification in 2003, and introduced exchange rate risk as another criterion in 2005 as part of its strategy to contain the growth of FC loans. In early 2008, it set higher provisioning rates for loans to unhedged FC borrowers. In December 2004, Serbia started requiring higher provisioning if minimum debt-service-to-income (DSTI) and LTV requirements were not met. It tightened loan classification further in 2005 but relaxed it in 2006 by only prescribing percentage bands for the calculation of special provisions and giving banks greater independence in credit risk measurement. Croatia introduced exchange rate risk as a criterion for loan classification in 2006. Bulgaria tightened classification rules in 2004 and 2005, but part of that tightening was reversed in late 2006.

- General provisions. Croatia introduced a system of dynamic provisioning in 2004 linking a bank's general provisions to its annual rate of credit growth. The threshold was 20 percent initially and was revised downward to 15 percent in 2006:Q3. Serbia introduced a system of dynamic provisioning similar to Croatia's (with a threshold of 15 percent) in mid-2008 just before the global crisis struck, before reversing course a few months later.

While tightening dynamic/general provisioning represents an immediately visible cost to banks, tightening specific provisioning rules during a boom does not necessarily do so, as in many cases the expense occurs only when the financial cycle has turned and asset quality starts deteriorating. Thus, it is likely that the former type of measure, if well calibrated, would be a more dissuasive measure than the latter.

\section{Liability-Based Reserve Requirements and Liquidity Ratios (LRR)}

The four countries also had different strategies with respect to the use of measures to manage the growth of liabilities. The following instruments were used:

- Average reserve requirements $(R R)$. In the two countries with a flexible exchange rate Romania and Serbia - classical liability-based reserve requirements were a key instrument to manage credit growth but also to promote the use of the domestic currency. Both countries expanded the set of liabilities subject to reserve requirements and increased significantly the rate applicable to FC-denominated liabilities while keeping the rate on domestic currency deposits stable or even lowering it. In Serbia, the rate on short-term borrowing from abroad reached a peak of 60 percent during the second half of 2006. In the other two countries with no or limited exchange rate flexibility, the use of the instrument was much more limited and had a greater focus on traditional liquidity management ${ }^{20}$, and no differentiation by currency was ever introduced. In fact, Croatia did not use the instrument for tightening purposes at all and in one instance it reduced reserve requirements rates when other instruments were tightened (Figure A2). ${ }^{21}$

\footnotetext{
20 The Croatia National Bank (CNB) October 13, 2004 press release stated that "The CNB Council decision reducing the reserve requirement rate from 19 to 18 percent, adopted at this meeting, corresponds to the attempts to stabilize the external debt balance at the present level. Total amount of reserve requirements will thus be reduced by around HRK $1.8 \mathrm{bn}$ : by approximately $1.1 \mathrm{bn}$ in the kuna component and $0.7 \mathrm{bn}$ in the foreign exchange component of reserve requirements. In that manner, the central bank facilitates the realization of the planned issue of government bonds, by means of which the Ministry of Finance intends to replace a portion of external debt with domestic borrowing. Reserve requirement reduction ensures a satisfactory banking system liquidity level for such a transaction. Since the government intends to use the collected kuna for an immediate purchase from the central bank of foreign exchange required for the repayment of Samurai bonds falling due in mid-December, such a purchase would offset the effect of this bond issue on the domestic monetary developments. This decision is also in accordance with the longterm policy of the Croatian National Bank, aimed at a gradual reserve requirement reduction."

21 The CNB December 7, 2005 press release states that "It is expected that with the increased marginal reserve requirement banks will have no economic interest in additional borrowing abroad. Nevertheless, they will still have ample liquidity, since the general reserve requirement rate was at the same time reduced from 18 to 17 percent. As a result of this change, which too will be applied as from the calculation date in January, banks will have 2.1 billion kuna at their disposal (of which two thirds in kuna and the remaining share in foreign exchange). The general reserve requirement rate is planned to be further reduced to 16 percent in the coming year. In this way, banks will be given room for total placements growth of over 10 percent, which will be sufficient to support economic growth and normal market demand."
} 
Marginal reserve requirements (MRRs) on foreign borrowing. Rather than stocks, Croatia preferred targeting specific flows. From mid-2004 until the end of the boom, it applied marginal reserve requirements on new foreign borrowing. Their rate was adjusted upwards several times, reaching 55 percent at the end of 2005 and remaining at that level until the instrument was abolished. The explicit objective was to slow down foreign borrowing of the banking sector and therefore the increase in external debt. Foreign parent banks reacted to the measure by substituting deposits and debt financing with capital injections and increasingly resorted to extending credit cross-border to Croatian corporations. A variant of MRRs on foreign borrowing called special reserve requirements (SRR) was introduced in 2006:Q1 and applied to some types of securities that banks had issued to circumvent the MRRs.

\section{Figure A2.}

Reserve Requirement Rates on Demand Deposits (Percent, 2002:Q3-2008:Q3)
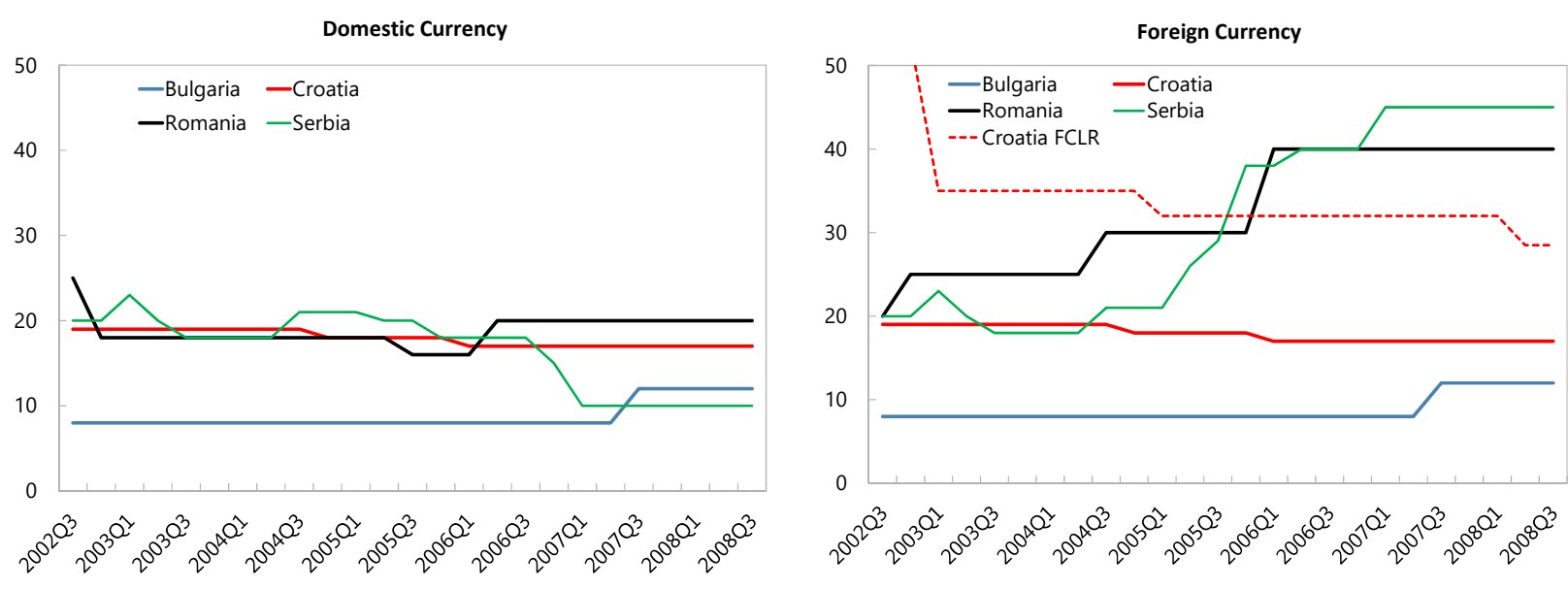

Note: FCLR = foreign currency liquidity requirement.

Source: Vandenbussche, Vogel, and Detragiache (2015), central bank websites and publications.

- Foreign currency liquidity ratio (FCLR). Entering the boom, Croatia and Serbia already had a regulation requiring that a large share of banks' short-term FC liabilities be covered by liquid FC claims. The purpose was to force banks to self-insure against the risk of a run on FC deposits. Croatia used that instrument during the boom by significantly reducing the rate while at the same time expanding its base. In particular, FC-indexed deposits were added to the base in late 2006 to close a circumvention channel that banks had been exploiting. Serbia marginally reduced the rate in 2004 and 2005 before dropping the instrument soon after the Serbian deposit insurance agency was created and depositor confidence got a boost. The FCLR instrument obviously interacted with the RR instrument as their rates and bases differed, making changes in one of the instruments not necessarily binding

\section{Asset-Based Reserve Requirements (ARR)}

A more direct way to control credit growth is to target it directly. That is what Croatia and Bulgaria did when they resorted to marginal reserve requirements related to credit growth. In Croatia, a first "credit ceiling" measure (penalizing quarterly credit growth in excess of 4 percent) was implemented during 2003. A second one, with a stricter threshold but a lower penalty rate, was implemented starting in early 2007. Bulgaria instituted similar credit ceilings in early 2005. They were to be phased out after1 year initially, but were then extended until the end of 2006. Penalties were increased in late 2005, and reduced in mid-2006. In both countries, the ARR were partly circumvented through booking with parent banks and booking with nonbank affiliates. In 
the case of Bulgaria, circumvention also took the form of extra booking before the reference date as soon as the measure was announced, which led the Bulgaria National Bank (BNB) to change the reference date ex post.

\section{E. Loan Eligibility Requirements (ELI)}

Perhaps surprisingly, only Romania made use of instruments which constrain credit demand by placing caps on the amounts that can be borrowed. They were implemented because "the identification of possible flaws in commercial banks' management of the main banking risks was a major concern of the supervisory authority. ${ }^{22}$ " An LTV limit of 75 percent was introduced in 2004:Q1. DSTI limits by type of loans (30 percent on consumer loans, 35 percent on mortgages) were introduced at the same time, and a DSTI limit of 40 percent covering total indebtedness was implemented in 2005:Q3. Both types of measures remained in place until the country entered the EU in January 2007 and banks were then allowed to set ceilings based on internal models. From August 2008, just before the crisis struck, Romania required banks to consider interest and exchange rate risk in setting the indebtedness ceiling.

\section{F. Regulation of Nonbank Credit Institutions (NBK)}

Partly as a result of the stricter regulation imposed on banks, nonbank credit institutions (leasing companies, consumer credit companies) began to thrive. Romania and Serbia brought these institutions into the regulatory perimeter in 2006:Q1. Serbia subjected them to a 10-percent reserve requirements measure on foreign borrowing, while Romania subjected them to the same loan eligibility requirement as banks.

\section{Macroprudential Measures Taken during the Bust}

The four countries reversed some of the tightening taken during the boom in order to avoid a credit crunch during the global financial crisis and the ensuing extremely severe recession. The most aggressive tightening measures had become redundant and were dropped early. Bulgaria and Serbia eased their capital regulation; provisioning rules were softened in all four countries. Croatia, Romania and Serbia reduced or altogether removed liability-based reserve requirements. Yet, and perhaps surprisingly, some tightening also took place, in particular in the area of loan eligibility criteria and capital requirements in Romania. This may reflect the realization that banks had failed to properly assess credit risk or to keep adequate buffers during the boom years and therefore that further regulatory constraints should be placed on their loan decision-making process. Overall, Serbia eased the most during the bust, just as it had tightened the most during the boom.

\section{A. Capital Regulation (CAP)}

- Changes in minimum CAR. None of the four countries reduced its minimum CAR during the bust, although three out of the four countries technically had regulatory space to do so (relative to the relevant Basel minima). In fact, as the crisis struck and Romania entered an IMF-and-EC-supported program, the National Bank of Romania asked all banks to maintain capital ratios above 10 percent, i.e. 2 percentage points above the statutory minimum. This requirement was still in place at end-2012. Croatia increased its minimum CAR from 10 percent to 12 percent in 2010:Q1 to compensate for the reduction in risk-weights on certain exposures at the time it implemented Basel II and which led to a mechanical increase in CAR by 2 percentage points. ${ }^{23}$

NBR 2003 Annual Report, p. 87.

23 See CNB 2010 Annual Report, p. 2. 
- Changes in specific risk-weights: In 2010:Q1, Bulgaria provided capital relief to banks through a cut of RW on household exposures to the minimum required by the European Capital Requirements Directive (CRD, i.e. the EU version of Basel II). A higher risk-weight for high-LTV housing loans was retained but the threshold was increased from 50 to 70 percent. Croatia and Serbia reduced risk-weights on household exposures and abandoned the riskweight surcharges on foreign currency loans when they adopted Basel II in early 2010 and late 2011 respectively. Both countries also introduced a higher risk-weight for high-LTV loans with a threshold set at 75 percent. Therefore, at the end of the period, all four countries had LTV-contingent risk-weights on mortgages, in line with the "substantial margin" requirement set in the EU's 2006 CRD.

- Changes in bank-specific minimum CAR that depend on credit growth. Croatia dropped this measure in 2010:Q1. The measure was far from binding at the time.

- Changes in specific leverage ratios. Serbia relaxed the quantitative limit on household lending by increasing the ceiling of the maximum ratio of household loans to share capital from 150 percent to 200 percent in 2009:Q1, and abandoned the measure altogether in the following quarter as "all objectives ... were met ... and it was no longer necessary to set a limit on bank household lending." 24

- Inclusion of current profits in the capital base: Romania and Bulgaria reversed the measure taken in the boom and allowed the recognition of current profit or profit from the previous year as a capital base element in 2009:Q2 and 2010:Q1 respectively. ${ }^{25}$

\section{B. Loan Classification and Provisioning (LCP)}

Loan classification and provisioning requirements were loosened in all four countries.

- Loan classification and specific provisions. Bulgaria, Romania and Serbia loosened the LCP rules during 2009-11. Bulgaria first slowed the rate of downgrades by increasing the number of days within each category of the classification, and later extended the allowed term of realization of real estate collateral. Romania allowed a fraction of the collateral to be deducted from the amount of exposures. Serbia first removed low down payments as a trigger for classification in the worst loan category, and later relaxed the DSTI thresholds triggering classification in one of the worst three categories.

- General provisions. Very early in the bust, Serbia and Croatia revoked the regulation requiring holding general provisions related to credit growth.

\section{Liability-Based Reserve Requirements and Liquidity Ratios (LRR)}

These measures were among the earliest to be loosened to help relieve liquidity pressures in banking systems.

- Standard reserve requirements. Countries reduced their reserve requirements both in terms of rates and in terms of base to relieve liquidity pressures in the banking system. In Bulgaria, the two-point reduction of reserve requirements early in the bust also allowed local affiliates of foreign banks to repay the liquidity support that had temporarily been provided by their parents soon after the onset of the global financial crisis. Romania and Serbia, which had increased significantly the rate on the foreign currency base during the boom, decreased it by an equivalently significant amount during the bust, although less so in the case of Serbia. At the end of the 2012, only in Serbia did the rates differ radically across currencies and reflected the explicit "dinarization" strategy pursued by the authorities in the post-crisis period (Figure A3). ${ }^{26}$

24 See NBS 2009 Annual Report, p. 47.

25 The BNB described this change as part of its "anticyclical policy in regulating banks' activities" (BNB 25 February 2010 press release).

26 See Markovic (2010). 
- Marginal reserve requirements. Croatia's MRR were completely revoked in October 2008 at the onset of the bust. SRR were lifted a few months later.

- Foreign currency liquidity ratio. Croatia reduced the FCLR rate from 28.5 percent to 20 percent in 2009:Q1 in the second half of 2008 at the onset of the recession. This was followed by a further reduction in 2011:Q1 to 17 percent with the aim of freeing foreign currency liquidity and stimulate investment. ${ }^{27}$ The set of eligible assets to meet the FCLR was expanded in 2012:Q2 to include 50 percent of the amount of loans granted in the context of the "loan program for the development of the economy" sponsored by the Croatian Bank for Reconstruction and Development (HBOR, in local spelling). ${ }^{28}$

\section{Asset-Based Reserve Requirements (ARR)}

Croatia dropped the credit growth reserve at the end of 2009 in the context of anemic credit growth.

\section{Figure A3.}

Reserve Requirement Rates on Demand Deposits (Percent, 2008:Q3-2012:Q4)
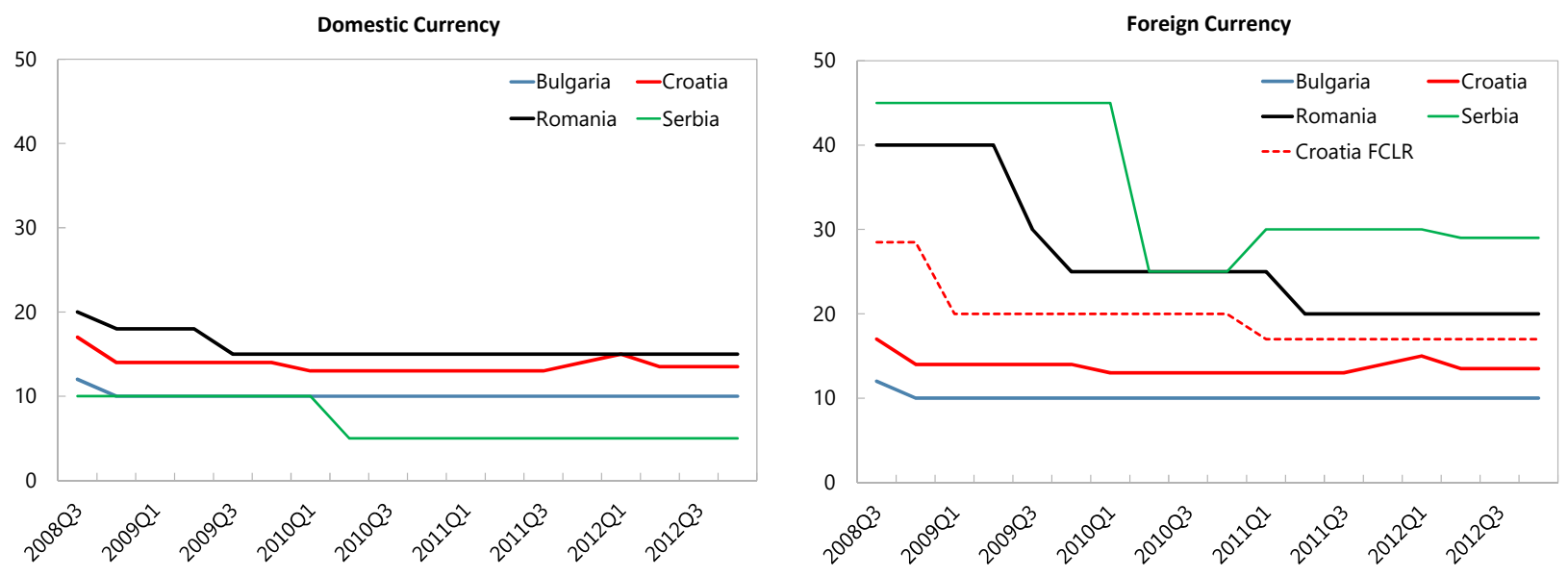

Note: FCLR=foreign currency liquidity requirement

Source: Vandenbussche, Vogel, and Detragiache (2015), central bank websites and publications.

\section{E. Loan Eligibility Requirements (ELI)}

As noted, this is one of the few areas in which some requirements were actually tightened during the bust period.

- Romania amended the rule it had introduced in August 2008 only two quarters later by removing the requirement to take into calculation interest rate risk and currency risk when setting the indebtedness ratio for clients taking loans backed by mortgages within city limits. In 2011:Q4, it then introduced a maximum LTV ratio by type of loan currency denomination and required specific FC shocks to be applied to determine borrowers' maximum indebtedness levels.

- In 2011:Q2, Serbia introduced a maximum LTV for foreign-currency-denominated or foreigncurrency-indexed loans. The ceiling was set at 80 percent for mortgages and 70 percent for other loans.

27 See CNB March 8, 2011 press release.

28 See http://www.hbor.hr/hbor-promotes-new-investments-through-new-forms-of 


\section{F. Regulation of Nonbank Credit Institutions (NBK)}

- In 2009:Q4, Romania reversed the rule allowing nonbank institutions to include interim profits in the calculation of own funds. This followed a similar easing rule for banks half a year earlier.

In addition to these measures, the four countries encouraged banks to implement conservative profit retention policies in 2009 and 2010 to fight the erosion of capital cushions because of the ongoing deterioration in asset quality. They also sought comfort letters from parent banks pledging adequate liquidity and capital support for their subsidiaries. In the case of Romania and Serbia, this was achieved in the context of the so-called Vienna Initiative. 


\section{List of Measures Taken by Country}

\section{List of Abbreviations of Macroprudential Instruments}

\begin{tabular}{ll}
\hline \hline \multicolumn{1}{c}{ Prudential Measure } & \multicolumn{1}{c}{ Description } \\
\hline CAP: CAPITAL MEASURES & \\
\hline mincap & Minimum required capital adequacy ratio \\
cap & Capital eligibility \\
cgrcap & Minimum required capital adequacy ratio as a function of credit growth \\
hhsc & Maximum on ratio of household loans to share capital \\
fcsc & Maximum on ratio of fc loans to own funds \\
basel & Basel II \\
rwmol & Risk weights / mortgage loans \\
rwmolfc & Risk weights surcharge/ FC mortgage loans \\
rwcons & Risk weights / consumer loans \\
rwconsfc & Risk weights surcharge/ FC consumer loans \\
rwcorp & Risk weights on corporate loans \\
rwcorpfc & Risk weights on fc corporate loans \\
\hline
\end{tabular}

\section{LCP: PROVISIONING MEASURES}

\begin{tabular}{ll}
\hline $\mathrm{gp}$ & Rules for general provisions \\
$\mathrm{dp}$ & Rules for specific provisions \\
$\mathrm{dpfc}$ & FC-loans rules for specific provisions \\
\hline
\end{tabular}

\section{LRR: LIABILITY-BASED LIQUIDITY MEASURES}

\begin{tabular}{ll}
\hline rr & Reserve requirements rate on LC deposits \\
rrfc & Reserve requirements rate on FC deposits \\
rrbase & Reserve requirements base \\
fclr & Foreign currency liquidity requirement \\
fclrbase & Foreign currency liquidity requirement base \\
mrr & Marginal reserve requirements \\
srr & Special reserve requirements \\
\hline ARR: ASSET-BASED LIQUIDITY MEASURES \\
\hline cgr & Credit growth reserve \\
cc & Marginal reserve requirements on credit growth above a threshold \\
\hline ELI: ELIGIBILITY MEASURES & \\
\hline ltv & Loan-to-value ceiling \\
ltvfc & FC loan-to-value ceiling \\
dsti & Debt-service-to-income ceiling \\
dstifc & FC debt-service-to-income ceiling \\
\hline
\end{tabular}

NBK: NONBANK REGULATORY POLICY 


\section{List of Measures Taken in the Period 2002-12 by Country}

\section{Bulgaria: Prudential Measures}

\begin{tabular}{l}
\hline \hline Quarter \\
\hline 2002Q1 \\
2002Q2 rrbase: exclusion of borrowed funds with a maturity over two years. \\
2002Q3 \\
2002Q4 \\
\hline 2003Q1 \\
2003Q2 \\
2003Q4
\end{tabular}

2004Q1

2004Q2 dp: evaluation and classification of risk exposures of banks was tightened as doubtful and loss exposures were consolidated into the non-performing loans category.

cap: ordnance on the capital adequacy was amended by setting out conditions for inclusion the retained profit from previous years and the current year profit in primary capital.

2004Q3 rrbase: increase in reserve requirement ratio to 4\% on long-term attracted resources (with maturity over two years) and repos of end-clients.

2004Q4 rrbase: rate on liabilities with maturity above two years raised from $4 \%$ to $8 \%$.

2005Q1

2005Q2 cc: introduction of credit ceilings: a bank is subject to marginal reserve requirements of 200\% if (i) it expands credit by more than 6\% per quarter on average, taking end-Q1 2005 as the base period; and (ii) the sum of its loans and the risk-weighted off-balance sheet items converted into assets, reduced by the amount of own funds, exceeds $60 \%$.

dp: loans overdue by more than 30 days, 60 days, or 90 days, have to remain classified as "watch," "substandard" and "non-performing," respectively, for a minimum of 6 months.

2005Q3 cap: regulatory minimum capital adequacy ratios must be satisfied while excluding current profits from the capital base.

rwmol_threshold: amendments to Regulation 8 were introduced: mortgage credits are treated with $50 \%$ risk weight only if the amount of credit is less than $70 \%$ of the value of collateral ( $70 \%$ loantovalue ratio), otherwise the risk-weight is $100 \%$.

2005Q4 cc: the penalty rate for breaching credit ceilings was temporarily increased for banks exceeding the limit by $1-2 \%$, from 200 to $300 \%$, and to $400 \%$ for excesses of more than $2 \%$.

dp: the provisioning requirements for impaired household credits was raised: from $10 \%$ to $20 \%$ for loans overdue by 30-60 days ("watch" category), and from 50\% to $75 \%$ for loans overdue by 60-90 days ("substandard" category).

2006Q1

2006Q2 rwmol: the risk weighting for mortgage loans used in the calculation of the capital adequacy ratio was effectively raised, by lowering the loan-to-value ratio threshold from $70 \%$ to $50 \%$.

2006Q3 cc: the progressive range of additional minimum required reserves was eliminated.

2006Q4 dp: the six-month period of keeping problematic mortgage and consumer loans in the classification groups "watch," "substandard" and "non-performing" was abolished when the regular service of these loans has been resumed. 
Bulgaria: Prudential Measures (continued)

Quarter

2007Q1 cc: end of credit limits.

basel: the implementation of a legal framework comprising the latest European directives introducing Basel II requirements; Bulgaria acceded to the European Union introducing compliance between Bulgarian legislation and European directives on credit institutions. Risk-weights under standardized approach are unchanged.

2007Q2

2007Q3 rr, rrfc: reserve requirements were increased from $8 \%$ to $12 \%$.

2007Q4

2008Q1

2008Q2

2008Q3

2008 Q4 rr, rrfc: reserve requirements were decreased from $12 \%$ to $10 \%$.

2009Q1 dp: the loan classification and provisioning rules were loosened by increasing the number of days within each classification category; loan restructuring through maturity extensions up to two years does not lead to reclassification.

rrbase: reducing the minimum required reserves on funds attracted by banks from abroad from $10 \%$ to $5 \%$ and removing the minimum reserve requirements on funds attracted from state and local government budgets.

2009Q2

2009Q3

2009Q4

2010Q1 cap: the requirement to hold a general shareholders' assembly for the recognition of current profit or profit from the previous year as a capital base element was dropped.

rwmol, rwmolfc, rwcons, rwconsfc: for banks using the standardized approach to credit risk, the risk-weight for retail exposures was reduced from $100 \%$ to $75 \%$, and the riskweight for mortgage exposures was reduced from $50 \%$ to $35 \%$ (loan-to-value from $50 \%$ to $70 \%$ ); however $100 \%$ risk weight remains in place if above the threshold.

2010Q2

2010Q3

2010Q4

2011Q1

2011Q2 dp: term of realization by banks of the collateral provided to them in the form of buildings or regulated land property was extended.

2011Q3

2011Q4

2012Q1

2012Q2

2012Q3

2012Q4 
Quarter

2002Q1

2002Q2

2002Q3

2002Q4

2003Q1 cgr: banks for which the growth of assets exceeded 4\% in a given quarter (equals 17\% annual growth) were required to buy low-yielding central bank paper: this rule was temporary and was kept in place only in 2003 , cover $200 \%$.

fclr, fclrbase: foreign currency liquidity requirement reduced from $53 \%$ to $35 \%$, but expanded base to include foreign currency long-term liabilities. Net tightening.

2003Q2

2003Q3

2003Q4

2004Q1 cgr: credit growth reserve dropped

gp: if growth of specific items of assets and off-balance sheet contingent liabilities exceeds $20 \%$, banks need to form and maintain provisions, and retain profits.

2004Q2

2004Q3 mrr: marginal reserve requirement rate on net foreign borrowing was initially set at $24 \%$.

2004Q4 rr: reserve requirements ratio was cut to $18 \%$.

2005Q1 fclr: the rate of minimum required liquid foreign currency claims was cut from $35 \%$ to $32 \%$. mrr: marginal reserve requirement rate was raised to $30 \%$.

2005Q2 mrr: marginal reserve requirement rate was raised to 40\%; base extended during the year several times.

2005Q3

2005Q4 mrr: marginal reserve requirement rate was raised to 55\%.

2006Q1 rr: reserve requirements ratio was reduced to $17 \%$.

srr: special reserve requirements on securities are calculated every second Wednesday in a month, by applying a $55 \%$ rate to the prescribed base.

2006Q2 rwmolfc, rwconsfc, rwcorpfc: risk weights on foreign currency or foreign currency-indexed loans to unhedged borrowers in non-government increased from 50\% to $75 \%$ (for mortgages) and from $100 \%$ to $125 \%$ (for others).

dpfc: banks are obliged to monitor, analyze and assess the adjustment of debtors' foreign exchange positions and adaptability of their cash flows to any variability in their liability levels which might occur as a result of exchange rate changes.

2006Q3 gp: tightened growth rate on extra countercyclical provisioning measure up to $15 \%$.

2006Q4 fclr: foreign currency liquidity requirement base included foreign currency indexed liabilities; final deadline for adjustment to $32 \%$.

2007Q1 cgr: credit growth reserve reimposed at 12\% annual growth, with cover of $50 \%$.

2007Q2

2007Q3

2007Q4 
Croatia: Prudential Measures (continued)

Quarter

2008Q1 rwmolfc, rwconsfc, rwcorpfc: risk weights for unhedged borrowers were increased by a further 25 percentage points: applied weights are 100\% (which replaced 75\%) and 150\%.

cgr: credit growth reserve penalty was increased to $75 \%$.

cgrcap: banks growing faster than $12 \%$ per year have to maintain a capital requirements rato higher than $12 \%$ plus $150 \%$ of credit growth above $12 \%$.

2008Q2 fclr: foreign currency liquidity requirement rate reduced to $28.5 \%$

2008Q3

2008Q4 mrr: marginal reserve requirements were abolished.

rr: reserve requirement rate was cut from $17 \%$ to $14 \%$.

2009Q1 srr: special reserve requirments were terminated.

fclr: foreign currency liquidity requirement reduced in two steps to $20 \%$.

dp: measure requiring additional general provision related to credit growth was dropped.

2009Q2

2009Q3

2009Q4 cgr: credit growth reserve was dropped.

2010Q1 rr: reserve requirement rate was cut from $14 \%$ to $13 \%$.

rwmol, rwmolfc, rwcons, rwconsfe, rwcorpfc, mincap: with the adoption of Basel II the very high risk weights were dropped but minimum captial adequacy requirements was increased to $12 \%$ from $10 \%$ to compensate; from now on risk weights on mortgages are contingent on the loan-to-value ratio: for a loan-to-value up to $75 \%$ the risk weight is $35 \%$, otherwise it is $100 \%$.

cgrcap: credit growth reserve cap was dropped.

dp: available for sale assets and some off-balance sheet items were excluded from the classification.

2010Q2

2010Q3

2010Q4

2011Q1 fclr: foreign currency liquidity requirement reduced from $20 \%$ to $17 \%$.

2011Q2

2011Q3

2011Q4 rr: reserve requirement rate was raised from $13 \%$ to $14 \%$.

2012Q1 rr: reserve requirement rate was raised from $14 \%$ to $15 \%$.

fclrbase: the minimum foreign currency liquidity requirement rate remained at $17 \%$, but the definition of foreign currency claims was broadened recognizing T-bills subscribed by banks as liquid foreign currency claims.

2012Q2 rr: reserve requirement rate was reduced from $15 \%$ to $13.5 \%$.

fclrbase: the calculation of minimum required foreign currency claims will also include $50 \%$ of the amount of bank loans granted to economic entities.

2012Q3

2012Q4 
Romania: Prudential Measures

Quarter

2002Q1

2002Q2

2002Q3

2002Q4 rr, rrfc: reserve ratios were reduced to $18 \%$ for reserves in domestic currency and raised to $25 \%$ for reserves in foreign currency.

2003Q1

2003Q2

2003Q3

2003Q4

2004Q1 Itv, dsti: consumer credit: installments shall not exceed 30\% of net incomes of the borrower and his family; downpayment of at least $25 \%$ or cosigner commitment for purchases of goods; collateral and/ or cosigner commitment for other types of consumer credit; mortgage credit: credit value shall not exceed $75 \%$ of the property value; installments shall not exceed $35 \%$ of net incomes of the borrower and his family.

2004Q2

2004Q3 rrfc: reserve requirement ratio on foreign currency deposits raised from $25 \%$ to $30 \%$, reserve ratio on domestic currency deposits remains at $18 \%$.

2004Q4

2005Q1 rrbase: reserve requirements broadened to include all foreign currency liabilities carrying maturities of over two years.

2005Q2

2005Q3 dsti: eligibility criteria further tightened; overall installments associated with the sum of all credit contracts shall not exceed $40 \%$ of net incomes.

rr: reserve requirements on domestic currency liabilities reduced from $18 \%$ to $16 \%$.

dpfc: regulation on provisioning and loan classification was refined to take into account the foreign currency risk of the borrower.

fcsc: foreign currency credit exposure of a credit institution arising from loans granted to unhedged individuals and legal persons shall not exceed $300 \%$ of own funds.

rrbase: reserve requirements base broadenend to include all foreign currency liabilities carrying maturities of over two years regardless of the date at which they were raised.

2005Q4

2006 Q 1 rrfc: reserve requirements on foreign currency liabilities raised from $30 \%$ to $35 \%$ and then to $40 \%$. other: non-bank credit institutions (leasing, financial credit, etc.) enter into the regulatory perimeter.

2006Q2 rr: reserve requirements increased from $16 \%$ to $20 \%$ (first time in 6.5 years).

2006Q3

2006Q4 other: eligibility constraints on household loans now also apply to regulated non-bank credit institutions.

2007Q1 mincap: following EU entry, minimum capital requirements drops from $12 \%$ to $8 \%$. dsti: eligibility criteria are now defined by banks' internal models.

Itv: loan-to-value limit was abandoned.

fesc: exposure limits lifted

2007Q2

2007Q3

2007Q4 
Romania: Prudential Measures (continued)

Quarter

2008Q1 dpfe: higher provisioning rate for loans to unhedged foreign currency borrowers.

rwmol: with the adoption of Basel II risk weights on mortgages were made contingent on the loan-tovalue ratio: for an loan-to-value up to $75 \%$ the risk weight is $35 \%$, otherwise it is $100 \%$.

basel: full enforcement of Basel II regulatory framework. Lower risk-weights (standardized approach).

2008Q2

2008Q3 cap: current year profits were excluded from regulatory capital.

dstifc: banks have to consider the interest and exchange rate risk in setting the indebtedness ceiling (set on a case by case basis by using internal risk models).

other: eliminate the possibility that non-bank financial institutions entered into the Special Register should include interim profit in the calculation of own funds.

2008Q4 rr: reserve requirementes on domestic currency liabilities reduced from $20 \%$ to $18 \%$.

2009Q1 dstifc: requirement to take into calculation interest rate risk and currency risk when setting the indebtedness ratio for clients taking loans backed by mortgage on the home or the land within city limits was removed.

mincap: the minimum capital adequacy ratio was set at $10 \%$ as long as the multilateral financing arrangement with the EU, the IMF and other IFIs was in place.

2009Q2 dp: a fraction of the collateral value (less than 25\%) can be deducted from the value of "loss" (i.e. $90+$ days overdue) exposures to compute provisions (under the old regulation, no deduction was allowed).

cap: reversal of August 2008 measure.

rrbase: reserve requirements on foreign currency liabilities with residual maturity greater than two years reduced from $40 \%$ to $0 \%$.

2009Q3 rr: reserve requirements on domestic currency liabilities reduced from $18 \%$ to $15 \%$.

rrfc: reserve requirements on foreign currency liabilities with maturity less than two years were reduced from $40 \%$ to $35 \%$ and later to $30 \%$.

2009Q4 other: regulation 20/2009 allows inclusion of interim profits in capital.

rrfe: reserve requirements on foreign currency liabilities with maturity less than two years were reduced from $30 \%$ to $25 \%$.

2010Q1

2010Q2

2010Q3

2010Q4

2011Q1

2011Q2 rrfc: reserve requirements on foreign currency liabilities with maturity less than two years reduced from $25 \%$ to $20 \%$.

2011Q3

2011Q4 Itv, Itvfc, dstifc: introduce a loan-to-value ceiling by type of loan currency denomination, and specific foreign currency shocks to determine the maximum indebtedness level. 
Serbia: Prudential Measures

Quarter

2002Q1

2002Q2 rrfc, rrbase: base for calculating reserve requirements was increased by including foreign currency deposits.

rr, rrfc: the reserve ratio was reduced from $24.5 \%$ to $20 \%$.

2002Q3

2002Q4

2003Q1 rr, rrfc: reserve requirements ratio raised from $20 \%$ to $23 \%$.

2003 Q2 rr, rrfc: further reduction of the rr ratio to $22 \%$, and to $20 \%$.

2003Q3 rr, rrfc: required reserve ratio reduced from $20 \%$ to $18 \%$ and kept unchanged until the end of the year.

2003Q4

2004Q1

2004Q2 fclr: banks are required to deposit 47\% (banks undergoing rehabilitation 100\%) of citizens' foreign exchange savings with the central bank.

2004Q3 rr, rrfc: increase of the reserve requirement rate from $18 \%$ to $21 \%$.

2004Q4 dp: if debt service-to-income exceed 30\% and down-payment is less than 20\%, classified as E and subject to $100 \%$ provisioning (exception: housing loans); before were subject to $25 \%$ provisioning.

2005Q1 mincap: minimum capital adequacy ratio was raised from $8 \%$ to $10 \%$, and later to $12 \%$.

rrbase: foreign currency base is extended: inclusion of liabilities arising from foreign currency loans from foreign legal entities with maturity up to four years and liabilities arising from unchanged remunerated sterilization of dinar foreign loans registered by banks.

2005Q2 rr, rrfc: introduction of a differentiated reserve: $20 \%$ on dinar reserve base and $26 \%$ on foreign currency reserve base.

rrbase: the base also included liabilities towards subsidiary and related banks abroad.

2005Q3 rrfe: reserve requirements on foreign exchange reserve calculation base was raised from $26 \%$ to $29 \%$. rrbase: base for calculation of foreign currency reserves was expanded to include liabilities in respect of credits from foreign legal entities with contracted maturity over four years; a 7\% ratio was applied on the expanded foreign exchange reserve base.

fclr: minimum foreign currency liquidity against foreign currency savings reduced from $47 \%$ to $45 \%$, then to $43 \%$.

2005Q4 rrbase: reserve requirements calculation base was reduced by the amount of long-term housing loans insured by government, but was expanded to include funds from abroad under transactions performed by the bank in the name and for the account of third parties; a differentiated ratio of 35\% was introduced and applied on foreign currency clause-indexed dinar deposits, later raised to $38 \%$; foreign currency base is extended.

rr: decrease of the reserve requirement rate applied to the dinar base from $20 \%$ to $18 \%$.

rrfc: further rise in foreign currency reserve requirement rate from $29 \%$ to $35 \%$, and then to $38 \%$.

dp: household loan classified in category $\mathrm{E}$ if no credit bureau report.

mincap: minimum capital adequacy ratio was raised to $12 \%$.

fclr: minimum foreign currency liquidity against foreign currency savings reduced from $43 \%$ to $42 \%$ in October, then to $42 \%$ in November, then dropped in December. 
Serbia: Prudential Measures (continued)

Quarter

2006Q1 other: the NBS took over the authority for regulating and supervising the leasing industry (Sept. 2005) and subjected leasing companies to a 10\% reserve requirement on foreign borrowing (Feb. 2006) rrfc: the reserve requirement ratio on foreign currency deposits and on foreign currency clauseindexed dinar deposits was raised from $38 \%$ to $40 \%$.

rrbase: foreign currency reserving base was expanded to include foreign currency subordinated obligations; deposits of leasing companies with banks are subject to $100 \%$ reserve requirement; the reserve requirements on foreign currency deposits and credits from abroad with repayment period of up to two years were increased from $40 \%$ to $60 \%$.

2006Q3 hhsc: obligation for banks to reconcile their gross household dinar loans and their share capital, so that it is lower than or equivalent to $200 \%$ of the value of share capital; loans for housing construction supported by government were excluded but amendment that foreign currency loans also have to be included.

2006 Q 4 rr: decrease in reserve requirements on dinar reserving base from $18 \%$ to $15 \%$.

$\mathrm{dp}$ : banks receive more independence for the calculations of special provisions; new debt serviceto-income criterion (including housing) included in provisioning rule: by applying criteria defined in their internal documents, banks are to classify into categories D or E all receivables from natural persons whose total monthly credit obligations, excluding obligations in respect of housing loans, exceed $30 \%$ of their regular net monthly income, or, including obligations in respect of housing loans, exceed $50 \%$ of their monthly income.

rwcorpfc: risk weights for foreign currency lending go up with new banking regulation to $125 \%$ for unhedged borrowers if borrowing amount is larger than 10 million dinars.

2007Q1 rr: decrease of reserve requirements on the dinar reserving base from $15 \%$ to $10 \%$.

rrfc: reserve requirement ratio on the foreign currency reserving base and a portion of the dinar reserving base made up of foreign currency-indexed dinar deposits was raised from $40 \%$ to $45 \%$.

rrbase: reserve requirement ratio on short-term external borrowing is reduced from $60 \%$ to $40 \%$ and a uniform reserve requirement ratio on dinar obligations arising from deposits and loans received from abroad was introduced and set at the level of $45 \%$ regardless of their maturity.

2007Q2 hhsc: tightened penalty measures for non-compliance and ordered banks to pay interest on the difference between the prescribed and the actually deposited amount of funds; stronger penalty measures against banks for the submission of inaccurate data resulting in the miscalculation of gross household lending to share capital ratios.

2007Q3 hhsc: the definition of gross household lending was changed to encompass all housing loans, including those supported by government program.

2007Q4 hhsc: the ratio of gross household lending to share capital was prescribed not to exceed $150 \%$ at the end of any calendar month.

rrbase: ratio on dinar liabilities under deposits with maturity of over one month was reduced to $5 \%$.

2008Q1

2008Q2 dpfc: minimum downpayment for consumer loans with foreign currency clause to avoid classification in category E increased from $20 \%$ to $30 \%$, but exclusion of credit cards and loans without foreign currency clause.

hhsc: extension of deadline to achieve the prescribed ratio for banks failing to comply.

2008Q3 gp: general provisions required if credit growth is larger than $15 \%$.

rwmolfc, rwconsfc: risks weights on fc-loans to households are increased by 25 pps: $75 \%$ for foreign currency-mortgage, $125 \%$ for foreign currency consumer loans.

2008Q4 rrbase: several easing measures regarding the calculation of the reserve requirement were taken, but ratios remained unchanged.

hhsc: further easing measures relating to the adjustment of gross household lending to share capital of bank and penalties were taken, for certain period.

gp: cancelled general provisions if credit growth larger than $15 \%$. 
Serbia: Prudential Measures (continued)

Quarter

2009Q1 rrbase: base for reserve requirement calculation reduced again, banks were exempted from calculation of reserve requirements on the amount of dinar- and foreign currency-denominated liabilities from deposits and credits received from abroad.

hhsc: ratio of household lending to share capital has to be lower or equal to $200 \%$ (instead of $150 \%$ )

dp, dpfc: suspended rule for higher provisioning if downpayment smaller than $30 \%$.

2009Q2 rrbase: base for reserve requirement calculation reduced again.

hhsc: cessation of validity of rule on ratio of household lending to share capital

2009Q3

2009Q4

2010Q1

2010Q2 rr: reduction in the reserve requirement ratio on the dinar base to 5\%.

rrfc: reduction in the reserve requirement ratio on the foreign currency base to $25 \%$, whilst the number of exemptions from required reserve calculation has been reduced.

rrbase: the number of exemptions from foreign currency reserve requirements was adjusted with significant effects of increased liquidity.

dp, dpfc: amendments to loan classification and provisioning rules by reducing provisioning for domestic currency credit and raising provisioning for foreign currency loans.

2010Q3

2010Q4

2011Q1 rrfc, rrbase: differentiated reserve ratios on both the dinar and foreign currency reserving base subject to the maturity of liabilities: dinar liabilities with maturity up to two years became subject to $5 \%$ ratio, while those with maturity over two years to $0 \%$ ratio; the ratio on foreign currency liabilities with maturity up to two years is set at $30 \%$ and that on liabilities with maturity over two years at $25 \%$.

2011Q2 Itvfc: introduced a set of measures regarding foreign currency-denominated and foreign currencyindexed lending to citizens: foreign currency-denominated and foreign currencyindexed loans may be approved only subject to a down payment or placement of deposit of no less than $30 \%$ of the loan amount; the loan-to-value of foreign currency-denominated and indexed mortgage loans are limited to a maximum of $80 \%$.

2011Q3

2011Q4 dp: lowering of the provisioning percentages for categories B, C and D; another change is that banks are no longer obliged to allocate reserves from earnings for a part of the special reserve for estimated losses that is not covered by allowances for impairment.

dpfc: prescribed that total monthly credit obligations are contracted in a considerable amount in foreign currency or in dinars with a foreign currency clause if at least $20 \%$ of those obligations are contracted in this way.

basel: Basel II implemented in December 2011.

2012Q1

2012 Q2 rrfc, rrbase: cut in foreign currency reserve requirement ratios from $30 \%$ to $29 \%$ for short maturities and from $25 \%$ to $22 \%$ for long maturities.

rrbase: raised to $50 \%$ the ratio on the portion of foreign currency reserve base comprised of foreign currency-indexed dinar liabilities.

2012Q3

2012Q4 dp: regulatory easing in respect to the recognition of mortgage as adequate collateral. 